\title{
Plant and insect herbivore community variation across the Paleocene-Eocene boundary in the Hanna Basin, southeastern Wyoming
}

\author{
Lauren E Azevedo Schmidt $^{\text {Corresp., } 1}{ }^{1}$, Regan E Dunn $^{2}$, Jason Mercer $^{1}$, Marieke Dechesne ${ }^{3}$, Ellen D Currano ${ }^{1,4}$ \\ 1 Botany, University of Wyoming, Laramie, WY, United States \\ 2 Field Museum of Natural History, Chicago, Illinois, United States \\ 3 U.S. Geological Survey, Geosciences and Environmental Change Science Center, Denver, CO, United States \\ ${ }^{4}$ Geology and Geophysics, University of Wyoming, Laramie, WY, United States \\ Corresponding Author: Lauren E Azevedo Schmidt \\ Email address: Ischmi19@uwyo.edu
}

Ecosystem function and stability are highly affected by internal and external stressors. Utilizing paleobotanical data gives insight into the evolutionary processes an ecosystem undergoes across long periods of time, allowing for a more complete understanding of how plant and insect herbivore communities are affected by ecosystem imbalance. To study how plant and insect herbivore communities change during times of disturbance, we quantified community turnover across the Paleocene-Eocene boundary in the Hanna Basin, southeastern Wyoming. This particular location is unlike other nearby Laramide basins because it has an abundance of late Paleocene and Eocene coal and carbonaceous shales and paucity of well-developed paleosols, suggesting perpetually high water availability.

We sampled approximately 800 semi-intact dicot leaves from five stratigraphic levels, one of which occurs late in the Paleocene-Eocene Thermal Maximum (PETM). Field collections were supplemented with specimens at the Denver Museum of Nature \& Science. Fossil leaves were classified into morphospecies and herbivore damage was documented for each leaf. We tested for changes in plant and insect herbivore damage diversity using rarefaction and community composition using NMDS ordinations. We also documented changes in depositional environment at each stratigraphic level to better contextualize the environment of the basin. Plant diversity was highest during the mid-late Paleocene and decreased into the Eocene, whereas damage diversity was highest at the sites with low plant diversity. Plant communities significantly changed during the late PETM and do not return to pre-PETM composition. Insect herbivore communities also changed during the PETM, but, unlike plant communities, rebound to their pre-PETM structure. These results suggest that insect herbivore communities responded more strongly to plant community composition than to the diversity of species present. 
1 Plant and insect herbivore community variation

2 across the Paleocene-Eocene boundary in the Hanna

3 Basin, southeastern Wyoming

Lauren E. Azevedo Schmidt ${ }^{1}$, Regan E. Dunn², Jason Mercer ${ }^{1}$, Marieke Dechesne ${ }^{3}$, Ellen D.

6 Currano $^{1,4}$

7

$8 \quad{ }^{1}$ Botany, University of Wyoming, Laramie, WY, USA

$9 \quad{ }^{2}$ Field Museum of Natural History, Chicago, IL, USA

$10{ }^{3}$ U.S. Geological Survey, Geosciences and Environmental Change Science Center, Box 25046 -

11 MS 980. Denver, CO 80225, USA

$12{ }^{4}$ Geology and Geophysics, University of Wyoming, Laramie, WY, USA

Corresponding Author:

Lauren E. Azevedo Schmidt ${ }^{1}$

Department of Botany, 1000 E. University Ave, Laramie WY 82070

Email address: 1schmi19@uwyo.edu

\section{Abstract}

Ecosystem function and stability are highly affected by internal and external stressors. Utilizing paleobotanical data gives insight into the evolutionary processes an ecosystem undergoes across long periods of time, allowing for a more complete understanding of how plant and insect herbivore communities are affected by ecosystem imbalance. To study how plant and insect herbivore communities change during times of disturbance, we quantified community turnover across the Paleocene-Eocene boundary in the Hanna Basin, southeastern Wyoming. This particular location is unlike other nearby Laramide basins because it has an abundance of late Paleocene and Eocene coal and carbonaceous shales and a paucity of well-developed paleosols, suggesting perpetually high water availability. 
31 collections were supplemented with specimens at the Denver Museum of Nature \& Science.

32 Fossil leaves were classified into morphospecies and herbivore damage was documented for each

33 leaf. We tested for changes in plant and insect herbivore damage diversity using rarefaction and

34 community composition using non-metric multidimensional scaling (NMDS) ordinations. We

35 also documented changes in depositional environment at each stratigraphic level to better

36 contextualize the environment of the basin. Plant diversity was highest during the mid-late

37 Paleocene and decreased into the Eocene, whereas damage diversity was highest at the sites with

38 low plant diversity. Plant communities significantly changed during the late PETM and do not

39 return to pre-PETM composition. Insect herbivore communities also changed during the PETM,

40 but, unlike plant communities, rebound to their pre-PETM structure. These results suggest that

41 insect herbivore communities responded more strongly to plant community composition than to

42 the diversity of species present.

\section{Introduction}

44 Many modern ecological studies focus on how ecosystems will adapt over the next 100 years as

45 anthropogenic climate change continues to alter terrestrial ecosystems, oftentimes faster than

46 plants and insects can adapt (Parmesan, 2006; Anderson, Panetta \& Mitchell-Olds, 2012;

47 Midgley \& Bond, 2015). What is to come after the hundred-year mark? Paleobotanical research

48 allows ecological questions to extend the century-long time scale by several orders of magnitude,

49 providing insight into the evolutionary processes of ecosystems as they respond to environmental

50 changes. Plant and insect herbivore food webs are ideal for studying ecosystem function as they

51 are highly influenced by internal and external factors such as changes in the diversity and

52 composition of primary producers and abiotic environmental conditions (Coviella \& Trumble,

53 1999). Food web dynamics of plants and insects are preserved within the rock record as 
54 biological markers of ecosystem function, allowing for a deep-time understanding of how these

55 communities responded to gradual and abrupt environmental changes as well as potentially

56 giving clues to what is the driving force behind the change (Labandeira \& Currano, 2013). By

57 better understanding how ancient ecosystems record both stability and instability within plant

58 and insect food webs, it may be possible to better interpret changes within modern ecosystems

59 and improve predictions on how future anthropogenic climate change will alter terrestrial trophic 60 dynamics.

61 Previous paleoecological studies have detailed how local communities were affected by

62 abrupt, global disruptions such as the Late Cretaceous bolide impact (66 million years ago, or

$63 \mathrm{Ma}$ ) and the Paleocene-Eocene Thermal Maximum (PETM, $56 \mathrm{Ma}$ ). Modern ecological studies

64 have shown that plant and insect diversity are often correlated however, this is not the case after

65 the Cretaceous-Paleogene extinction event (K-Pg). Following the Cretaceous bolide impact,

66 ecosystem function was highly variable among regions, as terrestrial plant and insect

67 communities experienced rebound (e.g. Vajda et al., 2001; Ellis \& Johnson, 2003; Wilf et al.,

68 2006; Iglesias et al., 2007; Wappler et al., 2009; Donovan et al., 2016). This instability

69 continued for the duration of the Paleocene in western North America, as evidenced by

70 inconsistencies in plant versus insect herbivore diversity (Wilf et al., 2006). As ecosystems in

71 the Western Interior, U.S.A. rebounded, they also experienced changing climate, from the

72 relatively cooler Paleocene to the "hothouse" Eocene (Zachos, Dickens \& Zeebe, 2008). This

73 gradual warming was punctuated by the PETM, a geologically abrupt perturbation to the global

74 carbon cycle and ultimately the energy budget of the planet (McInerney \& Wing, 2011). This

75 event, indicated in the rock record by a negative carbon isotope excursion resulting from a

76 massive release of greenhouse gases, caused global temperatures to increase $\sim 5-9^{\circ} \mathrm{C}$ and caused 
77 varied changes in precipitation regimes (McInerney \& Wing, 2011). The PETM transformed

78

79

80

81

82 83

84

85 86

87 88

terrestrial ecosystems in many ways, including the alteration and intensification of hydrologic

cycles (Schmitz \& Pujalte, 2007; Handley et al., 2008; Kraus et al., 2013), an increase in sedimentary flow rates and change in depositional systems (Foreman, Heller \& Clementz, 2012), turnover in abundant plant species (Smith, Wing \& Freeman, 2007; Wing \& Currano, 2013; Garel et al., 2014), and increased insect herbivory (Currano et al., 2008, 2016).

These studies encompass a limited geographic area; however due to the importance of the time interval, new localities capturing the terrestrial ecosystem are needed. The Hanna Basin, southeastern Wyoming (Figure 1) is ideal for research because of its thick and uninterrupted sequence of Paleocene-Eocene sediments (Smith \& Bowen, 1918), newly described PETM sections (Dechesne pers. comm., 2019), and rock types that suggest a different microclimate and paleoenvironment than existed in other well-studied Rocky Mountain basins. In contrast to the well-studied Eocene Willwood Formation in the Bighorn Basin, which contains highly oxidized red beds (Kraus, 2001), the Hanna Formation contains abundant coal beds, carbonaceous shales, and drab sandstones and siltstones that were deposited from the Paleocene through the early Eocene (Dobbin et al, 1929; Lillegraven \& Snoke, 1996; Dechesne pers. comm., 2019). These strata represent primarily fluvial, lacustrine and back swamp deposition with organic-rich poorly drained soils (i.e. histosols) that indicate high water availability throughout the interval. If Paleogene plant and insect communities had the same basic needs as modern ones, Hanna Basin plant and insect communities would not have been limited by water. Also, with elevated atmospheric $\mathrm{CO}_{2}$ in the Paleogene (Freeman \& Hayes, 1992), carbon would not have been limiting for plant growth either. 
100 Paleocene-Eocene boundary within the Hanna Basin and to better understand how changes in the 101 global energy budget are reflected at the regional level. Our dataset spans the late Paleocene102 early Eocene and integrates information from new field collections, museum specimens and a 103 literature review. Paleoclimate reconstructions were made for our study site to understand how 104 and if regional climate reflected changes in the global energy budget and to contextualize 105 changes in local plant and insect herbivore communities. Additionally, by investigating plant and insect dynamics as global climate change occurred and depositional environment varied within the basin, we can better apply our findings to future predictions of terrestrial ecosystem function through a turbulent time.

\section{Geologic Setting}

110 The western region of North America underwent substantial structural alterations during the Late

111 Cretaceous through the Eocene, starting with the closing of the Western Interior seaway.

112 Additionally, the Laramide orogeny, a low angle flat-slab subduction, transformed the landscape 113 gradually and altered the greater foreland basin into the Eocene (Dickinson et al., 1988). This

114 alteration resulted in smaller basins isolated by mountain ranges and uplifted arches (Ryan, 1977;

115 Dickinson et al., 1988) that extend from Canada $\left(\sim 54^{\circ} \mathrm{N}\right)$ to New Mexico $\left(\sim 34^{\circ} \mathrm{N}\right)$ that captured

116 thick, continuous sections of early Paleogene sediments. The Hanna Basin, an asymmetrical

117 fault-bounded basin located in southeastern Wyoming, is one such basin. Although relatively

118 small $\left(\sim 2600 \mathrm{~km}^{2}\right)$, it is a deep basin with thick, continuous sections of Late Cretaceous through

119 Eocene sedimentary rock (Blackstone, 1993).

The formation of interest in this study is the Hanna Formation which is approximately

1212100 meters in thickness and composed of alternating coal, shale, and sandstone (Smith \& 
122 Bowen, 1918; Dobbin et al, 1929). This formation has been interpreted as being fluvial, paludal

123 and lacustrine in deposition, with gradual shifts occurring between depositional environments (.

124 pers comm.,2019). Fluvial and swamp deposits are more prevalent in the central and western

125 parts of the basin, whereas paludal and lacustrine sediments dominate to the east. The basin is

126 dominated by paludal to lacustrine facies during the mid to late Paleocene (post 59 Ma) and

127 transitions to a fluvial dominated environment during the PETM. The PETM interval was

128 determined by Dechesne et al. (2017) using plant biostratigraphy (pollen and macrofossils) and

$129 \delta^{13} \mathrm{C}$ bulk organic carbon analyses. It includes coarse grained, laterally extensive channel

130 deposits referred to by Dechesne and colleagues as "Big Channel." The depositional

131 environment changed following the PETM as basin subsidence and infill continued, resulting in

132 a dominance of paludal to gradually more lacustrine strata (Dechesne et al., 2017).

133 Early and middle Paleocene floras from the Hanna Fm. and underlying Ferris Fm. were

134 described by Regan Dunn in an unpublished master's thesis (Dunn, 2003); Dunn's work includes

135 analyses of plant species composition, richness and abundance as well as paleobotanical

136 reconstructions of mean annual temperature and precipitation. Her study found that changes in

137 Paleocene floral richness were not linked to changes in reconstructed mean annual precipitation

138 (MAP) or mean annual temperature (MAT), but rather richness increased gradually through time

139 following the K-Pg extinction (Dunn, 2003). The two youngest sites collected by Dunn, Jingo

140 (DMNH 1.2725) and Wing Ding (DMNH 1.2630), are in the upper Hanna Fm. and are included in

141 this study. Here, we extend Dunn's work by documenting latest Paleocene and early Eocene

142 paleofloral composition within the Hanna Fm., reconstructing MAT and MAP for these floras,

143 and analyzing insect herbivore damage on the fossil floras.

\section{Materials \& Methods}


145 Field Sites

146 Field collections took place on private land with the authorization of Burt and Kay Palm of the

147 Palms Ranch, and Tad Anderson of Q Creek Ranch. We analyzed 807 semi-intact fossil dicot

148 leaves from 8 sites at 5 distinct stratigraphic levels (referred to here as Levels A-E, from lowest

149 to highest) within the Hanna Basin (Table 1). These strata span the late Paleocene, PETM and

150 early Eocene. Sites occur in two areas of the Hanna Basin, The Breaks and Hanna Draw (Figure

151 1), which are located approximately $8 \mathrm{~km}$ apart. Correlations between study areas were mapped

152 in the field and via aerial imagery (Google Earth). The stratigraphic levels studied in The Breaks

153 were structurally deformed dipping $\sim 43^{\circ}$ to the N-NW, whereas the strata within the Hanna

154 Draw section dips more shallowly $\left(\sim 14^{\circ}\right.$ to the N-NE). Stratigraphic placement of the floral sites

155 follows the coal bed nomenclature of Dobbin et al. (1929), in which coal beds and carbonaceous

156 shales were sequentially numbered from oldest to youngest. All sites were placed within a

157 detailed, high-resolution stratigraphic framework, which includes approximately $1250 \mathrm{~m}$ of

158 section at Hanna Draw and approximately 1100 m within The Breaks (Dechesne et al. 2017;

159 Figure 2). The age of the top of the section is constrained by a ${ }^{238} \mathrm{U} /{ }^{206} \mathrm{~Pb}$ zircon date of $54.42 \pm$

$160 \quad 0.27 \mathrm{Ma}$ obtained using four zircon crystals in a possible tonstein located above our highest

161 stratigraphic level (Dechesne pers. comm., 2019; Figure 2). However, most zircons analyzed in

162 this sample were Proterozoic or Paleozoic in age, suggesting that the zircons are detrital, and

16354.42 Ma represents a maximum estimate for deposition of this layer (Dechesne pers. comm.,

164 2019). Ages for the oldest floral localities studied here were estimated using linear sedimentation

165 rates constrained by the last occurrence of Tiffanian-3 mammals in The Breaks (estimated to be

$166 \sim 59.5 \mathrm{Ma}$ [see (Secord et al., 2006) for age control, and (Higgins, 2003) for mammal

167 biostratigraphy]) and the age of the CIE (56 Ma, Westerhold et al., 2009). 

no herbivory damage were tallied on the outcrop and discarded and voucher specimens were collected. All other fossils collected were labeled, wrapped, and transported back to the

171 University of Wyoming for further analysis (Figure 3). Vouchered specimens from the new 172 collections are housed at the University of Wyoming Museum of Geology.

173 The lowest stratigraphic level of this study (Level A), located approximately between

174 Coal 77 and Coal 78 in The Breaks, includes Jingo quarry (referred to here as Site A.1),

175 previously sampled by Dunn (2003). Jingo is approximately $2090 \mathrm{~m}$ (Figure 2) above the local

176 base of the Hanna Fm. in The Breaks as measured by Lillegraven \& Snoke (Lillegraven \&

177 Snoke, 1996). As museum collections (Denver Museum of Nature \& Science) from this site

178 were insufficient for herbivory analyses, additional leaf fossils were sampled from a new bench 179 quarry (Site A.2) located $0.25 \mathrm{~km}$ to the southeast, but lateral to Dunn's original quarry. The 180 depositional environment at this level has been interpreted as fluvial/lacustrine due to the 181 interbedded silt and very-fine grained dark grey sandstones with the occasional ripple bed. These

182 leaf-bearing fluvial silts and sands were deposited in a small delta atop lacustrine shales. Level 183 B, the Wing Ding locality collected by Dunn (2003), occurs approximately between Coal 78 and 18479 in The Breaks, approximately ten meters above Level A. This is the youngest site collected by 185 Dunn (2003), and like Jingo, Wing Ding is of similar fluvial/lacustrine deposition with laminated 186 silt and sandstones. Due to adequate museum collections from this site, no further collection was 187 done.

188 The next stratigraphic level studied within The Breaks (Level C; quarries C.1 and C.2) is 189 located between Coal 79 and 80, 51m above Level B and is also Paleocene in age. On the mm190 scale, there are alternating beds of light and dark grey very-fine grained sandstone and siltstone. 
191 Additionally, there are layers of ripples preserved throughout; these ripple beds are more

192 prevalent than at Level A. We interpret the depositional environment as lacustrine. Plant debris,

193 sticks, wood, and well-preserved leaf compressions are fossilized above and below the ripple

194 beds; however, no identifiable fossils are found in ripple beds. The lacustrine deposit is capped

195 by an orange, laterally continuous, fine- to coarse-grained sandstone.

196 The earliest Eocene sites collected for this study (Level D; quarries D.1, D.2 and D.3) are

197 located in the uppermost portion of the Big Channel complex, exposed at $183 \mathrm{~m}$ in a section

198 called "Big Channel Lateral (BCL)" which is located $2.5 \mathrm{~km}$ to the northeast the main Big

199 Channel section at Hanna Draw (Figure 2). These sites are believed to occur late in the PETM

200 because of their stratigraphic location within Big Channel and carbon isotope curves (Dechesne

201 pers. comm., 2019). Exposure of fossiliferous silty sandstone is limited, and rocks are highly

202 fractured, making excavation of fossils here challenging. D.1 consists of matted layers of fossil

203 leaves and organic debris within fine to very fine-grained sandstone. We interpret the deposit as

204 being a small pond, possibly an oxbow pond, due to the lithology and the presence of abundant

205 laminated bedding planes. D. 2 and D. 3 occur approximately $0.5 \mathrm{~m}$ above D. 1 and are interpreted

206 as being fluvial in deposition, possibly representing crevasse splays. The two localities are

207 approximately $150 \mathrm{~m}$ apart and occur in white, massive, fine-grained sandstone. Preservation at

208 D is poor due to the course sediment of the fluvial system. Due to the nature of the outcrop,

209 bench quarries were not feasible and sample sizes are small.

210 The highest stratigraphic level excavated (Level E; quarries E.1 and E.2) is located within

211 The Breaks (73m in Beer Mug Vista section, Figure 2), approximately $4 \mathrm{~km}$ north of the latest

212 Paleocene localities in the Beer Mug Vista section (Dechesne pers. comm., 2019). E.1 and E.2

213 ( $\sim 90 \mathrm{~m}$ apart) are comprised of fine-grained sandstone layers bounded by coarse-grained 
214 sandstone. Fossiliferous layers were preserved as matted organic rich layers with a sharp contact

215 to poorly consolidated, coarse-very coarse sandstone, and we interpret this stratigraphic level as

216 fluvial in deposition. E.1 was excavated via bench quarry while E.2 was heavily fractured,

217 allowing for large blocks to be excavated, split and analyzed on the outcrop. E.2 has the best

218 preservation of all stratigraphic levels, including the preservation of cuticle and fourth order

219 venation.

220 Laboratory Analyses

$221 \quad$ Fossils were sorted into leaf morphospecies based on the shape, marginal features and 222 vein characteristics described in Ellis et al. (2011). When diagnostic features were covered by 223 matrix, fossil leaves were prepared in the University of Wyoming Geological Museum using an 224 air scribe. Fossils leaves collected for this study were then compared to the morphotypes 225 described by Dunn (2003). Insect herbivore diversity and frequency were quantified on all 226 identifiable leaves, and damage morphotypes (DTs) were assigned using Labandeira et al. 227 (2007). Herbivore damage is distinguished from preservational damage, such as tearing or 228 decomposition after the leaf abscission, by the presence of thickened tissue around the damage 229 site (Labandeira, 2002). Herbivory was also analyzed for Dunn's Jingo (A.1) and Wing Ding (B) 230 collections at the Denver Museum of Nature \& Science.

231 We used the relationship observed in extant plant communities between the proportion of 232 dicot species with untoothed margins at a site (P) and the mean annual temperature (MAT) of the 233 site to estimate MAT of each stratigraphic level (equation 1) (Wolfe, 1979; Wilf, 1997).

234 Equation 2 was used to calculate standard deviation of MAT where $r$ represents the number of 235 species with entire margins (Wilf 1997).

$$
\mathrm{MAT}=30.6 \mathrm{P}+1.14
$$




$$
\sigma[\mathrm{MAT}]=30.6 \sqrt{\frac{P(1-\mathrm{P})}{\mathrm{r}}}
$$

236

237

238

239

240

241

242

243

244

245

246

247

248

249

250

251

252

253

254

255

Paleoprecipitation estimates are based on the relationship between the size of the leaves and mean annual precipitation (Wilf et al., 1998). Fossil leaf sizes were documented using size classes set by Raunkiaer (Raunkiaer, 1934). Using the known relationship between leaf area and mean annual precipitation of modern forests(Wilf et al., 1998), MAP was determined as

$$
\mathrm{MAP}=\mathrm{e}^{0.548\left(\sum \mathrm{a}_{\mathrm{i}} \mathrm{p}_{\mathrm{i}}\right)+0.768}
$$

where $\mathrm{p}_{\mathrm{i}}$ is the proportion of leaves in the size classifications and $\mathrm{a}_{\mathrm{i}}$ is the natural logarithm of leaf areas of the Raunkiaer size-classes (Wilf et al. 1998). The standard error for MAP was calculated using the standard error $(\mathrm{SE}=0.359)$ from Wilf et al (1998).

Rank abundance, floral diversity indices, species richness, evenness and overall composition were analyzed for both the 2017 collections and Dunn's thesis data (2003). Rank abundance curves were created for each stratigraphic level representing the proportion of abundant morphospecies. We used Shannon-Weiner diversity index to compare diversity among sites, all species are weighted the same regardless of dominance (Routledge, 1979; Iknayan et al., 2014). Rarefaction curves were created to analyze sampling effort at all stratigraphic levels and to standardize plant species richness based on sample size for comparison. Floral evenness was quantified for all stratigraphic levels using Pielou's J (Pielou, 1966a,b). Lastly, to understand how plant community composition changed across time and stratigraphic levels, NMDS ordinations were constructed using a matrix of floral abundances at each stratigraphic level and the function metaMDS in the package, Vegan (Oksanen et al., 2018). All NMDS analyses were run using the Euclidean distance metric on count data. All analyses were conducted using the platform R (“R Core Team,” 2018), version 3.5.1, and all R code is included in Appendix A3. 
257 frequency of herbivory and damage composition. Damage diversity is the number of DTs

258 observed, and it is heavily dependent on sample size; thus, we standardized by the number of

259 leaves analyzed (Schachat, Labandeira \& Maccracken, 2018). Rarefactions were calculated

260 using Gunkel and Wappler's (2015) methodology, which accounts for leaves with no damage

261 and leaves with multiple DTs. Rarefaction curves were generated for the total number of DTs

262 and specialized feeding DTs on the bulk flora at each stratigraphic level, as well as for the total

263 number of DTs on individual plant hosts with at least 20 leaves within a stratigraphic level.

264 Generalized feeding insect herbivores are non-selective of host plants, whereas specialized

265 feeding insects selectively feed on specific plant taxa. Specialized herbivores have adapted or

266 evolved to the plant defenses of their host taxon, illustrating coevolution between plant and

267 insect communities (Krieger, Feeny \& Wilkinson, 1971; Whittaker \& Feeny, 1971). Specialized

268 feeding is recognized in the fossil record when the morphology of damage is consistent with that

269 of known specialized feeders (e.g. miners and gallers) (Labandeira, 2002). Damage frequency

270 was analyzed as the percent of leaves in a sample with any, specialized or generalized damage.

271 NMDS ordinations were made to evaluate changes in herbivore damage composition across

272 stratigraphic levels utilizing a matrix of damage abundances and function metaMDS, Euclidean

273 distances and count data.

\section{Results}

275 A total of 65 distinct plant morphospecies were identified across the 5 stratigraphic levels. 21 276 morphospecies occur in the 2017 collections, and 44 morphospecies were part of Dunn's MS

277 thesis collections. Eight morphospecies are shared across the 2003 and 2017 collections.

278 Descriptions of each morphospecies from the 2017 collections are included in Appendix A4, 
279 summary tables of floral occurrences for each locality are listed in Appendix A5 and the full 280 census dataset is included in Appendix A6. Using the list of morphospecies and their 281 characteristics, MAT and MAP reconstructions for each stratigraphic level were calculated 282 (Table 1). MAT estimates range from $18.8 \pm 2.6^{\circ} \mathrm{C}$ (Level B) to $22.3 \pm 3.9^{\circ} \mathrm{C}$ (Level C). MAP $283(\mathrm{~cm} / \mathrm{yr}$ ) estimates range from $108+46.9,-32.7$ (Level D) to $184.0+79.3,-55.4$ (Level B). Due to 284 large error estimates and low species diversity, climate reconstructions are not meaningfully 285 different across stratigraphic levels. Continued sampling and the discovery of new species are 286 necessary to further refine climate reconstructions.

287 Floral rank abundance results are plotted for each stratigraphic level (Figure 4) and show 288 that levels C and E are heavily dominated by one or two taxa. Site A.1 (Dunn, 2003) has 21 289 morphospecies, two of which make up $\sim 40 \%$ of all specimens, HB077 (21.6\%) and HB104 290 (20.7\%). Site A.2 contained 14 morphospecies, and 20\% of specimens are morphospecies 291 HB176 (Figure 3C). Level B has a total of 33 morphospecies, and $40.6 \%$ of specimens are 292 morphospecies Averrhoites affinis (Figure 3F). At stratigraphic level C, a total of 306 fossil 293 leaves were analyzed and 14 morphospecies identified. C.1 is comprised of 12 different 294 morphospecies, with Platanites raynoldsii (Figure 3D) making up 59.1\% of specimens. C.2 has 29510 different morphospecies, and the two morphospecies with the highest relative abundance were 296 Trochodendroides genetrix (Figure 3B) at 43.4\% and Platanites raynoldsii (Figure 3D) at $42.1 \%$. 297 Stratigraphic level D has a total of 10 morphospecies. Morphospecies HB176 (Figure 3C) is the 298 most abundant leaf type at D.2 and D.3, whereas D.1 is dominated by HB180 (Figure 3G) 299 (27.5\%) and HB176 (Figure 3C) (22.5\%). Stratigraphic level E has a total of 19 morphospecies. 300 At both E.1 and E.2, morphospecies HB176 (Figure 3C) had the highest relative abundance 301 (30.8\% and 57.9\%, respectively). 

quarries and stratigraphic levels. Considering quarries with at least 40 specimens, E. 1 has both the

304 highest diversity and is the most even, compared to C.1 which has the lowest diversity and 305 evenness. Various other quarries show a discrepancy between diversity and evenness which is 306 likely due to sample size when dividing out each specific quarry. By binning individual quarries 307 together and analyzing the stratigraphic levels for Shannon diversity $(\mathrm{H}$; dominant and rare species 308 weighted similarly), we see that level A has the highest diversity $(H=2.7)$, and the lowest diversity is at Level $\mathrm{C}(H=1.30)$ along with the lowest evenness $(J=0.51)$. The stratigraphic level with the highest evenness is level $\mathrm{D}(J=0.82)$. It is important to note that both $\mathrm{C}$ and $\mathrm{E}$ have low diversity and evenness values, while stratigraphic levels A and D have similarly high diversity and evenness estimates. Floristic rarefaction curves for each stratigraphic level show that our sampling effort was insufficient in fully capturing floral richness at the sites as none of the curves reaches a sampling saturation plateau; additional collections are required to determine the true richness of the ecosystem (Figure 5A). Levels A and B have the highest plant richness with Levels $\mathrm{C}$ and $\mathrm{E}$ having the lowest. Results from Level D should be interpreted with caution because of the low sample size; however, due to the location of Level D within the late PETM we report the results. A total of 34 damage types (DTs) were recognized in this study. Herbivory rarefaction curves plot DT richness standardized by number of leaves analyzed (Figure 5B-C). All plots show that additional sampling is needed to capture the diversity of herbivory in each ecosystem as well. Levels $\mathrm{C}$ and $\mathrm{E}$ have the highest richness for both total (Figure 5B) and specialized damage (Figure 5C), despite having low plant species richness. In contrast, Levels A, B, and D

323 have lower total and specialized damage richness, although additional sampling at Level D is 
325 a stratigraphic level were plotted (Figure 6). Only levels C and E shared a plant morphospecies

326 (Platanites raynoldsii) that occurred at high enough abundance to analyze, and damage richness

327 in Level C is higher than in Level E (Figure 6).

328 The stratigraphic level with the highest frequency of herbivory is Level C (25.5\%) and

329 the lowest is Level D (11.4\%) (Figure 7A). Across all stratigraphic levels, generalist feeding

330 damage is more abundant than specialist feeding damage. Specialized feeding is the most

331 frequent at Level C and least frequent at Level D, however increased sample size at Level D is

332 needed to confirm this result. The ratio of specialized feeding to generalized feeding informs

333 about the prevalence and relative importance of specialist feeders within the insect herbivore

334 community. Levels A and B have the highest ratio of specialized to generalized damage across

335 stratigraphic levels, and Level D has the lowest ratio (Figure 7B).

336 A particular type of mining, DT38 (Figure 8), occurs at Level C on Platanites raynoldsii

337 and is characterized by numerous circular areas that resemble skeletonization. Today, similar

338 damage traces are made by members of the family Incurvariidae (Lepidoptera; Labandeira, pers.

339 comm). Another distinctive damage morphology, found on morphospecies HB177 at site E.2, is

340 similar to damage by the extant Chrysomelid beetle Odontota dorsalis, known to feed on

341 secondary veins (Scott Shell, pers. comm.). This damage is a specific type of skeletonization, in

342 which the secondary veins are thickened at the ends, suggesting that they were fed on (Figure 8).

343 Unlike other types of skeletonization, where only the intercostal areas are fed on, the veins on

344 this fossil have also been eaten, a damage pattern that is rare for skeletonizing insects because

345 chemical defense is distributed via venation (Caldwell, Read \& Sanson, 2016).

$346 \quad$ NMDS ordinations of plant and herbivore community structure are shown in Figure 9.

347 Considering plant community structure (Figure 9A), Levels A and B plot near one another in the 
348 lower left corner, with low scores on both axis 1 and axis 2. Level $\mathrm{C}$ has a similar axis 1 score,

349 but a high axis 2 score and plots at the top of the figure. This position is controlled by the

350 abundance of Platanites raynoldsii. Level E has a similar axis 1 score as Level C, but scores

351 lower on axis 2. This location is dictated by HB176, HB182 and Averrhoites affinis.

352 Stratigraphic Level D has a high axis 1 score and is the only site that plots on the right side of the

353 ordination. The location of Level D is controlled by the morphospecies HB180 (Figure 3G). For

354 herbivore community structure (Figure 9B), Levels A and B plot in distinct areas of the

355 ordination, while Levels $\mathrm{E}$ and $\mathrm{C}$ plot almost on top of one another. As in the plant community

356 structure NMDS, Level D is alone on the right-hand side of the graph. Influential damage types

357 are labeled in Figure 9B to visualize which DTs most influence the placement of stratigraphic

358 levels in the ordination. DT7 (hole feeding: curvilinear to rectilinear elongate perforations)

359 drives the placement of stratigraphic Level D on the right of the ordination, whereas DT69

360 (mining: circular to ellipsoidal with coprolites), 25 (surface feeding: elongate, narrow surface

361 feeding with constant width), 141 (mining: thin zigzag with frass) and 61 (skeletonization:

362 elongate and adjoined that follows $1^{\circ}$ and $2^{\circ}$ venation) are responsible for the distance between

363 Levels A and B. DT 49 (galling: circular, large fusanized core surrounded by distinct outer

364 thickened rim) and 78 (hole feeding: removal of tissue in three or more intercostal sections)

365 influence the proximity of $\mathrm{C}$ and $\mathrm{E}$.

\section{Discussion}

367 This study documents how Hanna Basin plant and insect communities changed across an 368 approximate three-million-year interval that spans the Paleocene-Eocene boundary. Here, we 369 examine potential abiotic and biotic factors driving the changes observed, including depositional 370 environment, water availability, the PETM, and co-occurrence of plants and insect herbivores. It 
371 is important to note, as discussed in the results section, that additional sampling is needed to

372 capture the full diversity of the ecosystems and provide more robust reconstructions of

373 paleoclimate and paleoecology.

374 The dominant depositional environment in our study system varies both temporally and

375 spatially across the landscape, which may have affected the composition and dominance-

376 diversity patterns in plant fossil assemblages. The ecosystems preserved within Levels A, B and

377 C are fluvio-lacustrine or lacustrine in nature while, Levels D and E were deposited in a strictly

378 fluvial system. Plants are relatively immobile and unable to move their physical location once

379 germination has occurred, and it is likely that small changes in depositional environment would

380 impact a community. As depositional environment changes, plant communities are at risk of

381 losing land for colonization, becoming isolated from resources and potentially becoming more

382 vulnerable to disturbances (Nilsson \& Svedmark, 2002). Changes in deposition can also alter

383 water availability and soil moisture content, reshuffling niche space on the landscape (Jorge

384 Soberón, 2007; Guisan et al., 2014). Lacustrine and fluvial environments differ in taphonomic

385 biases through varying levels of transport; lacustrine facies experience less transport than fluvial

386 environments which would impact the amount of autochthonous vs. allochthonous material (Ellis

$387 \&$ Johnson, 2013). Fluvial environments (allochthonous) tend to be more diverse because they

388 contain a mix of local and transported leaves and thus capture a greater source area; however,

389 with increased transport large leaves are also less abundant which biases our record towards

390 smaller leaves thus impacting precipitation reconstructions (Ellis \& Johnson, 2013).

391 Lithology and sedimentary structures at Levels A and B indicate a very similar

392 depositional environment, which we interpret as terminal splays draining into a paleo-lake. Plant

393 composition at these sites are compositionally quite similar, as indicated by the NMDS 
394 ordination. This similarity may also be a result of a mixture of allochthonous and autochthonous 395 material washed into the paleo-lake. The size and preservation of the leaves at both sites vary, as 396 might be expected in mixed source material. Between Level B and Level C, lake size and depth 397 increase, as indicated by changes in regional stratigraphy as well as local changes upward into a 398 siltstone and less ripple bedded sandstones at our Level C quarries. Plant composition at Level C 399 is significantly different, with low diversity and high dominance of Platanites raynoldsii. This 400 could be due to less land surface in the basin for species to colonize (Odum, 1969).

401 Alternatively, because Level C is likely a less dynamic environment than Levels A and B, the 402 leaves preserved here reflect less transport and a more localized environment. Lastly, the low 403 plant diversity could also be a reflection of preservational bias towards thicker, tougher leaves (e. 404 g., Platanites raynoldsii).

405 Concomitant with a change from a shallow lacustrine system to a predominantly fluvial 406 system is the PETM hyperthermal event as determined by carbon isotope stratigraphy (Dechesne 407 pers. comm., 2019). Elsewhere, this climatic event coincides with increased rates of weathering 408 and continental runoff (McInerney \& Wing, 2011; Foreman, Heller \& Clementz, 2012). It has 409 been hypothesized that increased runoff could be due to 1) increased transpiration from plant 410 communities (Betts et al., 2007), or 2) enhanced seasonality which may have caused opening of

411 forest canopies (Foreman, Heller \& Clementz, 2012). Either mechanism could explain the 412 formation of the stacked sand bodies of the Big Channel complex during the PETM in the Hanna 413 Basin. These hydrological changes and rise in global temperature may have impacted both plant 414 and insect communities. Plant species and insect herbivory preserved within Level D, which is 415 at the top of the Big Channel sequence, late in the PETM interval, shows a significant turnover 416 compared to pre- and post-PETM communities (Figure 9), a result consistent with the Bighorn 
417 Basin and other PETM floral records (Wing \& Currano, 2013). The increase in sediment flow

418 would have altered the landscape and impacted floral communities within.

In contrast to the Paleocene levels, the dominant depositional environment at Levels D

420

421

422

423

424

425

426

427

428

429

430

431

432

433

434

435

436

437

438

439

and $\mathrm{E}$ is fluvial; however, they differ slightly in their lithology and plant and insect communities.

The structures and stratigraphy of Level D suggest that the channel cut across the floodplain of a wetter environment; additionally, the irregular bases of the beds suggest the sediment load deformed the already wet bed that preceded it. Due to poor preservation, highly varied leaf sizes and lithology, the leaves preserved at this locality are likely a mix of autochthonous and allochthonous material. The larger leaves preserved at this site may be sourced locally whereas the smaller and more poorly preserved leaves may have traveled a longer distance. Additionally, the leaves preserved at this site are of poor quality because they are found within the sandstone of Big Channel Lateral. Unlike the crevasse splay deposits of Level D, Level E is interpreted as being proximal to the stream due to the sharp contacts between coarse-very course grained sand and organic rich layers. Sediment load was highly variable and would have rapidly fluctuated between higher and lower flow conditions (Rossetti, 2001). Leaves preserved within Level E are large and exceptionally well-preserved, suggesting minimal transport. These two sites (Levels D \& E) may vary in composition due to the PETM event, but there is also a vastly different energy regime at either site, impacting the preservation.

When comparing the lacustrine deposit of Level C and the fluvial deposit of Level E, we see that both are dominated by a single plant species (Platanites raynoldsii at Level C and HB176 at Level E) and have the highest diversity of insect herbivory. As lake levels rose, the available land for colonization decreased at Level C. This would have also been true for the location of Level E; with frequent flooding events, plants would have had limited area to 
440 colonize within this highly varied system. The decrease in evenness at these sites may also be 441 coupled with the rates of higher insect herbivory. Together, these two localities could give a 442 more complete representation of the paleo ecosystem within the Hanna Basin as they represent 443 two-end members of energy found within the system: the low energy of Level C with its finer 444 grained sediment and less frequent ripple beds, and a high energy flood system of Level E with 445 its sharp contact between course sediment and organic rich leaf layers.

447 environment did impact the plant and insect herbivore communities. Although we do not see a 448 clean signal of lacustrine vs. fluvial deposits, this is not surprising as all five localities are highly 449 varied in the finer details of their deposition. It is possible that the species:area relationship 450 coupled with depositional environment, as seen when comparing Levels $\mathrm{C}$ and $\mathrm{E}$, may show 451 similar patterns of plant occurrences and herbivory, even though the plant taxa are different. 452 Insect herbivores are highly influenced by changes in plant communities (Ali \& Agrawal, 453 2012; Richards et al., 2015), plant nutrient content (Coley, Bryant \& Chapin, 1985; Onoda et al., 454 2011), and temperature (Jamieson et al., 2012). Indirectly, insect communities are impacted by 455 changes in atmospheric $\mathrm{CO}_{2}$ via changes in plant nutrients (Dury et al., 1998; Hamilton et al., 456 2005; Dyer et al., 2013). Our analyses show that insect damage diversity does not track plant 457 diversity (Figure 5), contrary to expectations that as plant diversity increases, potential food 458 sources might also be expected to increase. Levels A and B have high plant richness but low total 459 and specialized damage diversity whereas Level $\mathrm{C}$ has low plant species richness but the highest 460 diversity and frequency of total and specialized damage. This is somewhat surprising result is 461 counter to modern studies linking high plant diversity to high insect herbivore diversity (Ebeling 462 et al., 2018; Schuldt et al., 2019), but is consistent with what Currano et al. (2010) reported for 
463 the Paleogene in the Bighorn Basin. There are several reasons why plant and insect damage

464 diversity are uncorrelated in our dataset. First, Level $\mathrm{C}$ has the lowest floral evenness and is

465 dominated by Platanites raynoldsii, a species that is common across the western USA during the

466 early Paleogene. According to Feeny's (1976) apparency hypothesis, plant taxa that are

467 regionally dominant are "bound to be found" by insect herbivores; they are apparent and, simply

468 put, more likely to be fed on. Additionally, there is incentive for insect species to evolve means

469 to overcome the defenses of apparent plant species and become specialist feeders on that

470 particular host. Platanites raynoldsii is heavily fed upon at Level C (Figure 6), where it is the

471 most abundant plant host, and there are several examples of specialized feeding damage on this

472 taxon (Figure 8). Alternatively, canopy structure, light availability and disturbance regime have

473 been shown to influence insect diversity, particularly in the Heteroptera and Coleoptera (Gobner,

474 2009; Currano et al., 2011; Schroeder, Buddle \& Saint-germain, 2019). These environmental

475 variables are difficult to reconstruct from fossils, and it is possible that variation among

476 stratigraphic levels affected insect herbivore diversity. Our work provides further evidence that

477 the relationship between plant diversity and insect herbivore diversity in both modern and

478 ancient ecosystems is variable and may be highly contingent on specific habitats (Wright \&

479 Samways, 1998; Wilf et al., 2006; Proches et al., 2009; Schuldt et al., 2019).

480 The percent of leaves with generalized, specialized and total feeding damage is varied

481 across stratigraphic levels with Level C having the highest percentage of all three (Figure 7A).

482 Similarly, Level E has the second highest percentage of all three damage categories. This is

483 reasonable because as we previously saw, Levels $\mathrm{C}$ and $\mathrm{E}$ had the highest total and specialized

484 damage diversity; however, what is particularly interesting is the ratio of specialized feeding to

485 generalized feeding is higher at Levels A and B (Figure 7B). As levels of plant diversity 
486 increased at Levels A and B, we see a higher frequency of specialized to generalized feeding.

487 This suggests that although overall plant and insect community structure do not track one 488 another, functional feeding groups may. With more diverse plant species, there is an added 489 benefit for insects to specialize in order to mitigate ever evolving plant defenses. These findings 490 contradict Feeny's apparency theory. Level D has the lowest frequency of total and specialized 491 herbivory, a surprising result because damage frequency and percent leaf area damage increase 492 in the Bighorn Basin during the PETM (Currano et al., 2008; Currano et al., 2016). New PETM 493 sites are needed to confirm this result.

494 Similarly, changes in insect damage composition appear to be largely independent of 495 changes in plant composition. Plant ordinations show that Levels A and B plot near one another 496 while the same localities are dissimilar in ordination space when comparing herbivory (Figure 9).

497 Levels $\mathrm{C}$ and $\mathrm{E}$ are very similar in terms of herbivory but not floral composition. In contrast, 498 both floral and herbivore composition at Level D are distinct when compared to sites before and 499 after. Insects experienced a significant turnover during the PETM (Level D), mirroring plant 500 community change, however they returned to a very similar community structure as seen prior to 501 the carbon isotope excursion. Floral and insect herbivore turnover during and after the PETM has 502 also been reported in the Bighorn Basin and was attributed to an increase in temperature, shift to 503 seasonally dry conditions, and changes in plant nutritional quality (Currano, Labandeira \& Wilf, 504 2010; Wing \& Currano, 2013; Currano et al., 2016). Discovery of new paleobotanical localities 505 in the Hanna Basin is necessary to increase our sample size and number plant species recovered, 506 improve estimates of MAT and MAP change (or lack thereof) during the PETM and determine

507 whether climatic forcing drove changes to plant and insect herbivore communities, as it did in 508 the Bighorn Basin. Alternatively, the biota may be tracking changes in nutrient cycling or 
509 changes to another limiting factor not quantified here. Previous studies have shown that stressed

510 plants increase nitrogen flow, resulting in higher levels of nitrogen within leaves (White, 1984).

511 This relationship between nitrogen, water availability and stress could explain why plant and

512 herbivore communities track one another during times of disturbance, specifically Level D which 513 occurs late in the PETM.

514 When comparing the Hanna Basin to the Bighorn Basin, one distinction between the two

515 basins is the difference in water availability, indicated by the abundance of coal and

516 carbonaceous shales in the Hanna Fm. Although carbonaceous shale deposits are known from

517 the contemporaneous Willwood Fm. of the Bighorn Basin (Kraus \& Gwinn, 1997; Davies-

518 Vollum \& Kraus, 2001), the magnitude of these deposits is significantly less than within the

519 Hanna Basin. Additionally, the well-developed paleosols of the Bighorn Basin suggest drying

520 during the PETM (Kraus, 1996; Kraus \& Riggins, 2007). Based on lithology alone, it is

521 reasonable to assume that the plant and animal communities within the Hanna Basin had more

522 available water when compared to the Bighorn Basin. Modern wetland studies have shown how

523 plant physiological processes respond to changes in water availability and the overall effects of

524 drought tolerance (Touchette et al., 2007; Erwin, 2009; Nardini \& Luglio, 2014). Plants

525 experiencing drought are highly susceptible to predation, desiccation and mortality (Breshears et

526 al., 2009; Mcdowell, 2011; Meineke \& Frank, 2018); thus it is reasonable to infer that plants

527 with ample available water could more effectively mitigate insect herbivore attacks during abrupt

528 climatic changes (Meineke \& Frank, 2018). As leaf venation and morphologic traits are tied to

529 water availability (Xu et al., 2009), it is logical to conclude that with high water availability the

530 morphologic signal these species are preserving is not truly related to climate but rather the

531 available water supply, dictated by the composition of soils. More research is needed to better 
532 understand plant responses to high water availably as atmospheric $\mathrm{CO}_{2}$ and temperature changes,

533 and ultimately, how this impacts plant defenses against herbivory (Onoda et al., 2011; Richards

534 et al., 2015).

\section{Conclusions}

536 In order to systematically understand our future, we must document background changes in

537 ecosystem function as anthropogenic climate change ramps up over the next century. The

538 paleoenvironments preserved within the Hanna Basin allows for a comparison of changes to

539 floral and insect herbivore communities during a time of highly variable global climate. In this

540 study we found that plant and insect herbivore diversity, along with community composition, did

541 not track one another; however, changes in both plant and insect community composition and

542 structure coincide with the PETM event. Additionally, we found that generalized feeding was

543 more abundant than specialized feeding, and we did not see an increase in damage frequency or

544 diversity during the PETM interval. This may be due to taphonomic and preservational

545 constraints, and the discovery of new PETM localities is needed to corroborate these findings.

546 The plant and insect communities preserved within the Hanna Basin had a unique response to the

547 PETM when compared to the Bighorn Basin WY. Much previous research has focused around

548 understanding how temperature and $\mathrm{CO}_{2}$ impact flora and fauna on a landscape, but as suggested

549 here, other abiotic factors such as water availability and depositional setting are also important

550 factors to consider as we push forward in the Anthropocene.

\section{Acknowledgements}

552 We would like to thank the Denver Museum of Nature \& Science for allowing access to

553 additional fossil specimens, the University of Wyoming Geologic Museum for providing access

554 for fossil preparation, and research assistants, Sarah Fanning and Lukas Lindquist. Additionally, 
555 we would like to recognize that field collections were made on the indigenous land of the

556 Arapaho and Cheyenne tribes.

557

558 


\section{References}

560 Ali JG., Agrawal AA. 2012. Specialist versus generalist insect herbivores and plant defense.

561 Trends in Plant Science 17:293-302. DOI: 10.1016/j.tplants.2012.02.006.

562 Anderson JT., Panetta AM., Mitchell-Olds T. 2012. Evolutionary and ecological responses to 563 anthropogenic climate change. Plant Physiology 160:1728 LP - 1740. DOI:

564 10.1104/pp.112.206219.

565 Betts RA., Boucher O., Collins M., Cox PM., Falloon PD., Gedney N., Hemming DL., 566 Huntingford C., Jones CD., Sexton DMH., Webb MJ. 2007. Projected increase in

567

568

569

570

571

572

573

574

575

576

577

578

579

580

581 continental runoff due to plant responses to increasing carbon dioxide. Nature 448:10371041. DOI: $10.1038 /$ nature06045.

Blackstone DL. 1993. Overview of the Hanna, Carbon, and Cooper Lake Basins, Southeastern Wyoming. The Geologic Survey of Wyoming.

Breshears D., Myers OB., Meye CW., Barnes FJ., Zoul CB., Allen CD., McDowell NG., Pockman WT. 2009. Tree die-off in response to global change- type drought : mortality insights from a decade of plant water potential measurements. Ecological society 7:185189. DOI: $10.1890 / 080016$.

Caldwell E., Read J., Sanson GD. 2016. Which leaf mechanical traits correlate with insect herbivory among feeding guilds? Annals of Botany 117:349-361. DOI: 10.1093/aob/mcv178.

Coley PD., Bryant JP., Chapin FS. 1985. Resource availability and plant antiherbivore sefense. Science 230:895-899. DOI: 10.1126/science.230.4728.895.

Coviella CE., Trumble JT. 1999. Effects of elevated carbon dioxide on insect-plant interactions. Conservation Biology 13:700-712. DOI: 10.1046/j.1523-1739.1999.98267.x. 
582 Currano ED., Jacobs BF., Pan AD., Tabor NJ. 2011. Inferring ecological disturbance in the fossil

583 record: A case study from the late Oligocene of Ethiopia. Palaeogeography,

584 Palaeoclimatology, Palaeoecology 309:242-252. DOI: 10.1016/j.palaeo.2011.06.007.

585 Currano ED., Labandeira CC., Wilf P. 2010. Fossil insect folivory tracks paleotemperature for 586 six million years. Ecological Monographs 80:547-567. DOI: 10.1890/09-2138.1.

587 Currano ED., Laker R., Flynn AG., Fogt KK., Stradtman H., Wing SL. 2016. Consequences of 588 elevated temperature and $\mathrm{pCO} 2$ on insect folivory at the ecosystem level: perspectives from 589 the fossil record. Ecology and Evolution 6:4318-4331. DOI: 10.1002/ece3.2203.

590 Currano ED., Wilf P., Wing SL., Labandeira CC., Lovelock EC., Royer DL. 2008. Sharply

591 increased insect herbivory during the Paleocene-Eocene Thermal Maximum. Proceedings of 592 the National Academy of Sciences of the United States of America 105:1960-1964. DOI: $593 \quad 10.1073 /$ pnas.0708646105.

594 Davies-Vollum KS., Kraus MJ. 2001. A relationship between alluvial backswamps and avulsion 595 cycles: An example from the Willwood Formation of the Bighorn Basin Wyoming. 596 Sedimentary Geology 140:235-249. DOI: 10.1016/S0037-0738(00)00186-X.

597 Dechesne M., Currano ED., Dunn RE., Higgins P. 2017. PETM response of a swampy fluvial to 598 lacustrine system in a rapidly subsiding basin, Hanna Basin, Wyoming, USA. In: CBEP 599 2017. Snow Bird, UT, 1-10.

600 Dickinson WR., Klute MA., Hayes MJ., Janecke SU., Lundin ER., Mckittrick MA., Olivares 601 MD. 1988. Paleogeographic and paleotectonic setting of Laramide sedimentary basins in 602 the central Rocky Mountain region. Bulletin of the Geological Society of America 603 604 Donovan MP., Iglesias A., Wilf P., Labandeira CC., Cúneo NR. 2016. Rapid recovery of 
605 Patagonian plant-insect associations after the end-Cretaceous extinction. Nature Ecology \& 606 Evolution 1. DOI: 10.1038/s41559-016-0012.

607 Dunn RE. 2003. Correlation of leaf megafossil and palynological data with North American land 608 mammal ages from Paleocene strata of the Ferris and Hanna Formations, Hanna Basin, 609 South-Central, Wyoming.

610 Dury SJ., Good JEG., Perrins CM., Buse A., Kaye T. 1998. The effects of increasing CO2and 611 temperature on oak leaf palatability and the implications for herbivorous insects. Global 612 Change Biology 4:55-61. DOI: 10.1046/j.1365-2486.1998.00102.x.

613 Dyer LA., Richards LA., Short SA., Dodson CD. 2013. Effects of CO2 and temperature on $614 \quad$ tritrophic interactions. PLoS ONE 8. DOI: 10.1371/journal.pone.0062528.

615 Ebeling A., Rzanny M., Lange M., Eisenhauer N., Hertzog LR., Meyer ST., Weisser WW. 2018. 616 Plant diversity induces shifts in the functional structure and diversity across trophic levels. 617 Oikos 127:208-219. DOI: 10.1111/oik.04210.

618 Ellis B., Johnson KR. 2013. Comparison of leaf samples from mapped tropical and temperate 619 forests: Implications for interpretations of the diversity of fossil assemblages. Palaios 620 28:163-177. DOI: 10.2110/palo.2012.p12-073r.

621 Ellis B., Johnson KR., Dunn RE. 2003. Evidence for an in situ early Paleocene rainforest from 622 Castle Rock, Colorado. Rocky Mountain Geology 38:73-100. DOI:

623 10.2113/gsrocky.38.1.173.

624 Erwin KL. 2009. Wetlands and global climate change: The role of wetland restoration in a 625 changing world. Wetlands Ecology and Management 17:71-84. DOI: 10.1007/s11273-008$6269119-1$.

627 Foreman BZ., Heller PL., Clementz MT. 2012. Fluvial response to abrupt global warming at the 
628 Palaeocene/Eocene boundary. Nature 491:92-95. DOI: 10.1038/nature11513.

629 Freeman KH., Hayes JM. 1992. Fractionation of carbon isotopes by phytoplankton and estimates

630 of ancient CO2 levels. Global Biogeochemical Cycles 6:185-198. DOI:

$631 \quad 10.1029 / 92 \mathrm{~GB} 00190$.

632 Garel S., Quesnel F., Jacob J., Roche E., Le Milbeau C., Dupuis C., Boussafir M., Baudin F.,

633 Schnyder J. 2014. High frequency floral changes at the Paleocene-Eocene boundary

634 revealed by comparative biomarker and palynological studies. Organic Geochemistry

635 77:43-58. DOI: 10.1016/j.orggeochem.2014.09.005.

636 Gobner MM. 2009. Light intensity affects spatial distribution of Heteropter in deciduous forests.

637 European Journal of Entomology 106:241-252.

638 Guisan A., Petitpierre B., Broennimann O., Daehler C., Kueffer C. 2014. Unifying niche shift

639 studies : insights from biological invasions. Trends in Ecology \& Evolution 29:260-269.

640 DOI: $10.1016 /$ j.tree.2014.02.009.

641 Hamilton JG., Zangerl AR., Knepp RG., DeLucia EH., Mohan JE., Berenbaum MR. 2005.

642 Elevated $\mathrm{CO} 2$ reduces leaf damage by insect herbivores in a forest community. New

643 Phytologist 167:207-218. DOI: 10.1111/j.1469-8137.2005.01399.x.

644 Handley L., Pearson PN., McMillan IK., Pancost RD. 2008. Large terrestrial and marine carbon

645 and hydrogen isotope excursions in a new Paleocene/Eocene boundary section from

646 Tanzania. Earth and Planetary Science Letters 275:17-25. DOI:

$647 \quad$ 10.1016/j.eps1.2008.07.030.

648 Higgins P. 2003. A Wyoming succession of Paleocene mammal-bearing localities bracketing the

649 boundary between the Torrejonian and Tiffanian North American Land Mammal "Ages."

650 Rocky Mountain Geology 38:247-280. DOI: 10.2113/gsrocky.38.2.247. 
651 Iglesias A., Wilf P., Johnson KR., Zamuner AB., Cúneo NR., Matheos SD., Singer BS. 2007. A

652 Paleocene lowland macroflora from Patagonia reveals significantly greater richness than 653 North American analogs. Geology 35:947-950. DOI: 10.1130/G23889A.1.

654 Iknayan KJ., Tingley MW., Furnas BJ., Beissinger SR. 2014. Detecting diversity: Emerging 655 methods to estimate species diversity. Trends in Ecology and Evolution 29:97-106. DOI: $656 \quad$ 10.1016/j.tree.2013.10.012.

657 Jamieson MA., Trowbridge AM., Raffa KF., Lindroth RL. 2012. Consequences of climate 658 warming and altered precipitation patterns for plant-insect and multitrophic interactions. 659 Plant Physiology 160:1719-1727. DOI: 10.1104/pp.112.206524.

660 Jorge Soberón. 2007. Grinnellian and Eltonian niches and geographic distributions of species. 661 Ecology Letters 10:1115-1123. DOI: 10.1111/j.1461-0248.2007.01107.x.

662 Kraus MJ. 1996. Avulsion deposits in lower Eocene alluvial rocks, Bighorn Basin, Wyoming. 663 Geoscience World 66. DOI: 10.1306/D4268347-2B26-11D7-8648000102C1865D.

664 Kraus MJ. 2001. Sedimentology and depositional setting of the Wilwood Formation int he 665 Bighorn and Clarks Fork Basin. Papers on Paleontology 33:15-28.

666 Kraus MJ., Gwinn B. 1997. Facies and facies architecture of Paleogene floodplain deposits, 667 Willwood Formation, Bighorn Basin, Wyoming, USA. Sedimentary Geology 114:33-54. 668 DOI: $10.1016 / \mathrm{S} 0037-0738(97) 00083-3$.

669 Kraus MJ., McInerney FA., Wing SL., Secord R., Baczynski AA., Bloch JI. 2013.

670 Paleohydrologic response to continental warming during the Paleocene-Eocene Thermal 671 Maximum, Bighorn Basin, Wyoming. Palaeogeography, Palaeoclimatology, 672 Palaeoecology 370:196-208. DOI: 10.1016/j.palaeo.2012.12.008.

673 Kraus MJ., Riggins S. 2007. Transient drying during the Paleocene-Eocene Thermal Maximum 
674

675

676

677

678

679

680

681

682

683

684

685

686

687

688

689

690

691

692

693

694

695

696

(PETM): Analysis of paleosols in the bighorn basin, Wyoming. Palaeogeography, Palaeoclimatology, Palaeoecology 245:444-461. DOI: 10.1016/j.palaeo.2006.09.011.

Krieger RI., Feeny PP., Wilkinson CF. 1971. Detoxication enzymes in the guts of caterpillars:

An evolutionary answer to plant defenses? Science 172:579-581. DOI:

10.1126/science. 172.3983 .579 .

Labandeira CC. 2002. The history of associations between plants and animals.

Labandeira CC., Currano ED. 2013. The fossil record of plant-insect dynamics. Annual Review of Earth and Planetary Sciences 41:287-311. DOI: 10.1146/annurev-earth-050212-124139.

Lillegraven J., Snoke A. 1996. A new look at the Laramide orogeny in the Seminoe and Shirley Mountains, Freezeout Hills, and Hanna Basin, south-central Wyoming.

Mcdowell NG. 2011. Mechanisms linking drought, hydraulics , carbon metabolism, and vegetation mortality. American Society of Plant Biologists 155:1051-1059. DOI:

$10.1104 /$ pp. 110.170704.

McInerney FA., Wing SL. 2011. The Paleocene-Eocene Thermal Maximum: A perturbation of carbon cycle, climate, and biosphere with implications for the future. Annual Review of Earth and Planetary Sciences 39:489-516. DOI: 10.1146/annurev-earth-040610-133431.

Meineke EK., Frank SD. 2018. Water availability drives urban tree growth responses to herbivory and warming. Journal of Applied Ecology 55:1701-1713. DOI: 10.1111/13652664.13130 .

Midgley GF., Bond WJ. 2015. Future of African terrestrial biodiversity and ecosystems under anthropogenic climate change. Nature Climate Change 5:823.

Nardini A., Luglio J. 2014. Leaf hydraulic capacity and drought vulnerability: Possible trade-offs and correlations with climate across three major biomes. Functional Ecology 28:810-818. 
DOI: $10.1111 / 1365-2435.12246$.

698 Nilsson C., Svedmark M. 2002. Basic principles and ecological consequences of changing water 699 regimes: Riparian plant communities. Environmental Management 30:468-480. DOI:

$700 \quad 10.1007 / \mathrm{s} 00267-002-2735-2$.

701 Odum EP. 1969. The strategy of ecosystem development. Science 164:262-270.

702 Oksanen J., Blanchet FG., Friendly M., Kindt R., Legendre P., McGlinn D., Minchin PR., 703 O’Hara RB., Simpson GL., Solymos P., Stevens MHH., Szoecs E., Wagner H. 2018.Vegan. 704 Available at https://cran.r-project.org/package=vegan

705 Onoda Y., Westoby M., Clissold FJ., Cornelissen JHC., Fine PVA., Jerome J. 2011. Global 706 patterns of leaf mechanical properties. Ecology Letters 14:301-312. DOI: 10.1111/j.1461$707 \quad$ 0248.2010.01582.x.

708 Parmesan C. 2006. Ecological and evolutionary responses to recent climate change. Annual 709 Review of Ecology, Evolution, and Systematics:637-669. DOI:

710 10.1146/annurev.ecolsys.37.091305.110100.

711 Pielou EC. 1966a. The measurement of diversity in different types of biological collections. 712 Journal of Theoretical Biology 13:131-144. DOI: 10.1016/0022-5193(66)90013-0.

713 Pielou EC. 1966b. Species-diversity and pattern-diversity in the study of ecological succession. 714 Journal of Theoretical Biology 10:370-383. DOI: 10.1016/0022-5193(66)90133-0.

715 Proches S., Forest F., Veldtman R., Chown SL., Cowling RM., Johnson SD., Richardson DM., 716 Savolainen V. 2009. Molecular phylogenetics and evolution dissecting the plant - insect 717 diversity relationship in the Cape. Molecular Phylogenetics and Evolution 51:94-99. DOI: $718 \quad$ 10.1016/j.ympev.2008.05.040.

719 R Core Team 2018. Available at https://www.r-project.org/ 
720 Raunkiaer C. 1934. The life forms of plants and statistical plant geography; being the collected 721 papers of C. Raunkiaer. Oxford: Clarendon Press.

722 Richards LA., Dyer LA., Forister ML., Smilanich AM., Dodson CD., Leonard MD., Jeffrey CS. 723 2015. Phytochemical diversity drives plant - insect community diversity. PNAS 112:10973724 10978. DOI: $10.1073 /$ pnas. 1504977112 .

725

726

727

728

729

730

731

732

733

734

735

736

737

738

739

740

741

742

Rossetti DD. 2001. Late Cenozoic sedimentary evolution in northeastern Para, Brazil, within the context of sea level changes. Journal of South American Earth Sciences 14:77-89. DOI: 10.1016/S0895-9811(01)00008-6.

Routledge RD. 1979. Diversity indices: Which ones are admissible? Journal of Theoretical Biology 76:503-515. DOI: 10.1016/0022-5193(79)90015-8.

Ryan J. 1977. Late Cretaceous and early Tertiary provenance and sediment dispersal, Hanna and Carbon Basins, Carbon County, Wyoming: Geological Survey of Wyoming.

Schachat SR., Labandeira CC., Maccracken SA. 2018. The importance of sampling standardization for comparisons of insect herbivory in deep time: a case study from the late Palaeozoic. Royal Society Biological Sciences 5. DOI: 10.1098/rsos.171991.

Schmitz B., Pujalte V. 2007. Abrupt increase in seasonal extreme precipitation at the PaleoceneEocene boundary. Geology 35:215-218. DOI: 10.1130/G23261A.1.

Schroeder B., Buddle CM., Saint-germain M. 2019. Activity of flying beetles ( Coleoptera ) at two heights in canopy gaps and intact forests in a hardwood forest in Quebec. The Canadian Entomologist 520:515-520. DOI: 10.4039/n09-022.Downloaded.

Schuldt A., Ebeling A., Kunz M., Staab M., Guimarães-steinicke C., Bachmann D., Buchmann N., Durka W., Fichtner A., Fornoff F., Härdtle W., Hertzog LR., Klein A., Roscher C., Schaller J., Oheimb G Von., Weigelt A., Weisser W., Wirth C., Zhang J., Bruelheide H., 
743

744

745 Secord R., Gingerich PD., Smith ME., Clyde WC., Wilf P., Singer BS. 2006. Geochronology and 746

747

748

749

750

751

752

753

754

755

756

757

758

759

760

761

762

763

764

765

Eisenhauer N. 2019. Multiple plant diversity components drive consumer communities across ecosystems. Nature Communications 10. DOI: 10.1038/s41467-019-09448-8. mammalian biostratigraphy of Middle and Upper Paleocene continental strata, Bighorn Basin, Wyoming. American Journal of Science 306:211-245. DOI: 10.2475/04.2006.01.

Smith GO., Bowen CF. 1918. Stratigraphy of the Hanna Basin, Wyoming. United states geological survey 108:227-235.

Smith FA., Wing SL., Freeman KH. 2007. Magnitude of the carbon isotope excursion at the Paleocene-Eocene thermal maximum: The role of plant community change. Earth and Planetary Science Letters 262:50-65. DOI: 10.1016/j.eps1.2007.07.021.

Touchette BW., Iannacone LR., Turner GE., Frank AR. 2007. Drought tolerance versus drought avoidance: A comparison of plant-water relations in herbaceous wetland plants subjected to water withdrawal and repletion. Wetlands 27:656-667. DOI: 10.1672/02775212(2007)27[656:DTVDAA]2.0.CO;2.

Vajda V., Raine JI., Hollis CJ. 2001. Indication of global deforestation at the Cretaceous-Tertiary boundary by New Zealand fern spike. Science 294:1700-1702. DOI: 10.1126/science. 1064706.

Wappler T., Currano ED., Wilf P., Rust J., Labandeira CC. 2009. No post-Cretaceous ecosystem depression in European forests? Rich insect-feeding damage on diverse middle Palaeocene plants, Menat, France. Proceedings of the Royal Society B: Biological Sciences 276:42714277. DOI: $10.1098 / \mathrm{rspb} .2009 .1255$.

Westerhold T., Röhl U., McCarren HK., Zachos JC. 2009. Latest on the absolute age of the Paleocene-Eocene Thermal Maximum (PETM): New insights from exact stratigraphic 
position of key ash layers + 19 and - 17. Earth and Planetary Science Letters 287:412-419. DOI: 10.1016/j.eps1.2009.08.027.

768 White TCR. 1984. The abundance of invertebrate herbivores in relation to the availability of 769 nitrogen in stressed food plants. Oecologia 63:90-105. DOI: 10.1007/BF00379790.

Whittaker RH., Feeny P. 1971. Allelochemics: chemical interactions between species. Science $171: 757-770$.

772

Wilf P. 1997. When are leaves good thermometers? A new case for leaf margin analysis.

774

775 Paleobiology 23:373-390.

Wilf P., Labandeira CC., Johnson KR., Ellis B. 2006. Decoupled Plant and Insect Diversity After the End-Cretaceous Extinction. Science 313:1112-1116. DOI: 10.1126/science.1129569.

776 Wilf P., Wing SL., Greenwood DR., Greenwood CL. 1998. Using fossil leaves as

777 paleoprecipitation indicators: An Eocene example. Geology 26:203-206. DOI:

778 10.1130/0091-7613(1998)026<0203:UFLAPI $>2.3 . C O$.

779 Wing SL., Currano ED. 2013. Plant response to a global greenhouse event 56 million years ago. 780 American Journal of Botany 100:1234-1254. DOI: 10.3732/ajb.1200554.

781 Wolfe JA. 1979. Temperature parameters of humid to mesic forests of Eastern Asia and relation 782 to forests of other regions of the Northern Hemisphere and Australasia. U.S. Geological 783 Survey Professional Paper 1106:1-37.

784 Wright M., Samways MJ. 1998. Insect species richness tracking plant species richness in a 785 diverse flora: gall insects in the Cape Floristic Region, South Africa. Oecologia 115:427$786 \quad 433$.

787 Xu F., Guo W., Xu W., Wei Y., Wang R. 2009. Leaf morphology correlates with water and light 788 availability: What consequences for simple and compound leaves. Progress in Natural 
$789 \quad$ Science 19:1789-1798. DOI: 10.1016/j.pnsc.2009.10.001.

790 Zachos JC., Dickens GR., Zeebe RE. 2008. An early Cenozoic perspective on greenhouse

791 warming and carbon-cycle dynamics. Nature 451:279-283. DOI: 10.1038/nature06588.

792 


\section{Table $\mathbf{1}$ (on next page)}

Locality summary table

Locality summary table. Equation 1-3 were used for climate reconstruction. All data collected, and analyses made by Dunn (2003) are denoted with a superscript of $(*)$. Climate estimates for Level A were made using a pooled dataset of Dunn's collections and the 2017 collections. 


\begin{tabular}{|c|c|c|c|c|c|c|c|c|c|c|}
\hline \multirow[t]{2}{*}{ Table 1: } & \multicolumn{5}{|c|}{ LATE PALEOCENE } & \multicolumn{3}{|c|}{ PETM } & \multicolumn{2}{|c|}{ EARLY EOCENE } \\
\hline & A.1 & A. 2 & B & C.1 & C. 2 & D.1 & D.2 & D.3 & E.1 & E.2 \\
\hline $\begin{array}{c}\text { Sample Size } \\
(\mathrm{n})\end{array}$ & $224^{*}$ & 92 & $452^{*}$ & 229 & 75 & 5 & 40 & 11 & 61 & 265 \\
\hline $\begin{array}{l}\text { Species } \\
\text { Richness } \\
\text { (quarry) }\end{array}$ & $20^{*}$ & 13 & $41^{*}$ & 12 & 10 & 3 & 10 & 6 & 12 & 16 \\
\hline $\begin{array}{c}\text { Species } \\
\text { Richness } \\
\text { (strat. level) } \\
\end{array}$ & \multicolumn{2}{|c|}{30} & $41^{*}$ & \multicolumn{2}{|c|}{13} & \multicolumn{3}{|c|}{13} & \multicolumn{2}{|c|}{17} \\
\hline LMAT $\left({ }^{\circ} \mathrm{C}\right)$ & \multicolumn{2}{|c|}{$\begin{array}{c}18.48 \\
\pm 2.6 \\
\end{array}$} & $\begin{array}{l}18.8^{*} \\
\pm 2.6\end{array}$ & \multicolumn{2}{|c|}{$\begin{array}{r}22.3 \\
\pm 3.4 \\
\end{array}$} & \multicolumn{3}{|c|}{$\begin{array}{r}22.3 \\
\pm 3.9 \\
\end{array}$} & \multicolumn{2}{|c|}{$\begin{array}{l}19.1 \\
\pm 3.7 \\
\end{array}$} \\
\hline MAP (cm/yr) & \multicolumn{2}{|c|}{$\begin{array}{c}145 \\
+62.6 \\
-43.7\end{array}$} & $\begin{array}{r}184^{*} \\
+79.3 \\
-55.4 \\
\end{array}$ & \multicolumn{2}{|c|}{$\begin{array}{r}99 \\
+42.7 \\
-29.82 \\
\end{array}$} & \multicolumn{3}{|c|}{$\begin{array}{r}104 \\
+45.0 \\
-31.4 \\
\end{array}$} & \multicolumn{2}{|c|}{$\begin{array}{r}142 \\
+61.2 \\
-42.8 \\
\end{array}$} \\
\hline $\begin{array}{l}\text { Lithology and } \\
\text { depositional } \\
\text { environment }\end{array}$ & \multicolumn{3}{|c|}{$\begin{array}{l}\text { Fluvial/lacustrine. Thinly } \\
\text { bedded siltstone and fine- } \\
\text { grained sandstones with plant } \\
\text { debris and ripples }\end{array}$} & \multicolumn{2}{|c|}{$\begin{array}{l}\text { Lacustrine. Thinly } \\
\text { bedded sand and } \\
\text { siltstone with } \\
\text { alternating ripple } \\
\text { beds }\end{array}$} & $\begin{array}{l}\text { Oxbow } \\
\text { pond. } \\
\text { Laminated } \\
\text { bedding } \\
\text { and fine to } \\
\text { very fine- } \\
\text { grained } \\
\text { sandstone. }\end{array}$ & \multicolumn{2}{|c|}{$\begin{array}{l}\text { Fluvial. Massive } \\
\text { sandstone body } \\
\text { with fine-grained } \\
\text { sediment. Big } \\
\text { Channel complex. }\end{array}$} & \multicolumn{2}{|c|}{$\begin{array}{c}\text { Fluvial. Large } \\
\text { sandstone body } \\
\text { with coarse } \\
\text { (almost gravel) to } \\
\text { fine-grained sand. } \\
\text { Yellow in color. }\end{array}$} \\
\hline
\end{tabular}




\section{Table 2 (on next page)}

Diversity indices table

Diversity index and evenness metric for each quarry and stratigraphic level. Values calculated by Dunn (2003) denoted with a superscript of (*). For stratigraphic level A, data was pooled from Dunn's 2003 work and our 2017 collections. 


\begin{tabular}{|c|c|c|c|c|c|c|c|c|c|c|}
\hline \multirow[t]{2}{*}{ Table 2: } & \multicolumn{5}{|c|}{ LATE PALEOCENE } & \multicolumn{3}{|c|}{ PETM } & \multicolumn{2}{|c|}{ EARLY EOCENE } \\
\hline & A.1* & A. 2 & $\mathrm{~B}^{*}$ & C.1 & C.2 & D.1 & D.2 & D.3 & E.1 & E.2 \\
\hline $\begin{array}{l}\text { Shannon } \\
\text { Diversity } \\
\text { (quarry) }\end{array}$ & $2.06^{*}$ & 2.03 & $2.24^{*}$ & 1.26 & 1.26 & 1.33 & 1.94 & 1.54 & 1.93 & 1.53 \\
\hline $\begin{array}{l}\text { Shannon } \\
\text { Diversity } \\
\text { (strat. Level) }\end{array}$ & \multicolumn{2}{|c|}{2.70} & $2.24^{*}$ & \multicolumn{2}{|c|}{1.30} & \multicolumn{3}{|c|}{2.08} & \multicolumn{2}{|c|}{1.72} \\
\hline $\begin{array}{l}\text { Pielou's J } \\
\text { (quarry) }\end{array}$ & $0.73^{*}$ & 0.79 & $0.67^{*}$ & 0.51 & 0.55 & 0.96 & .84 & 0.86 & 0.78 & 0.55 \\
\hline $\begin{array}{l}\text { Pielou's J } \\
\text { (strat. Level) }\end{array}$ & \multicolumn{2}{|c|}{0.80} & $0.67^{*}$ & \multicolumn{2}{|c|}{0.51} & \multicolumn{3}{|c|}{0.82} & \multicolumn{2}{|c|}{0.61} \\
\hline
\end{tabular}




\section{Figure 1}

Basin Map

(A) Geologic map of Hanna Basin, WY. Inset of US map shows location of the Hanna Basin within Wyoming. (B) Base map of Hanna Basin showing the location of each quarry site, modified from Dechesne pers. comm., 2019. 

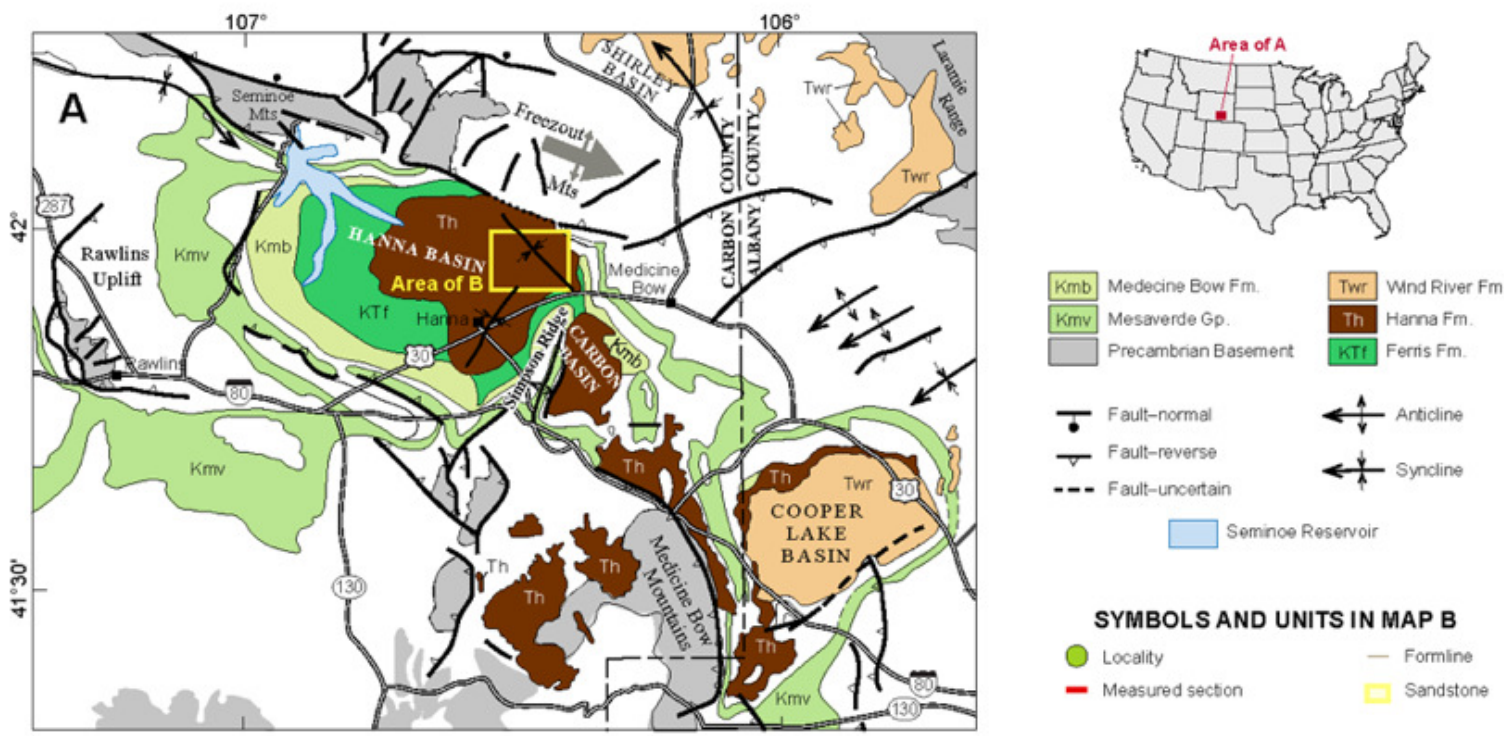

SYMBOLS AND UNITS IN MAP B

Locality

- Formine

- Measured section

Sandstone

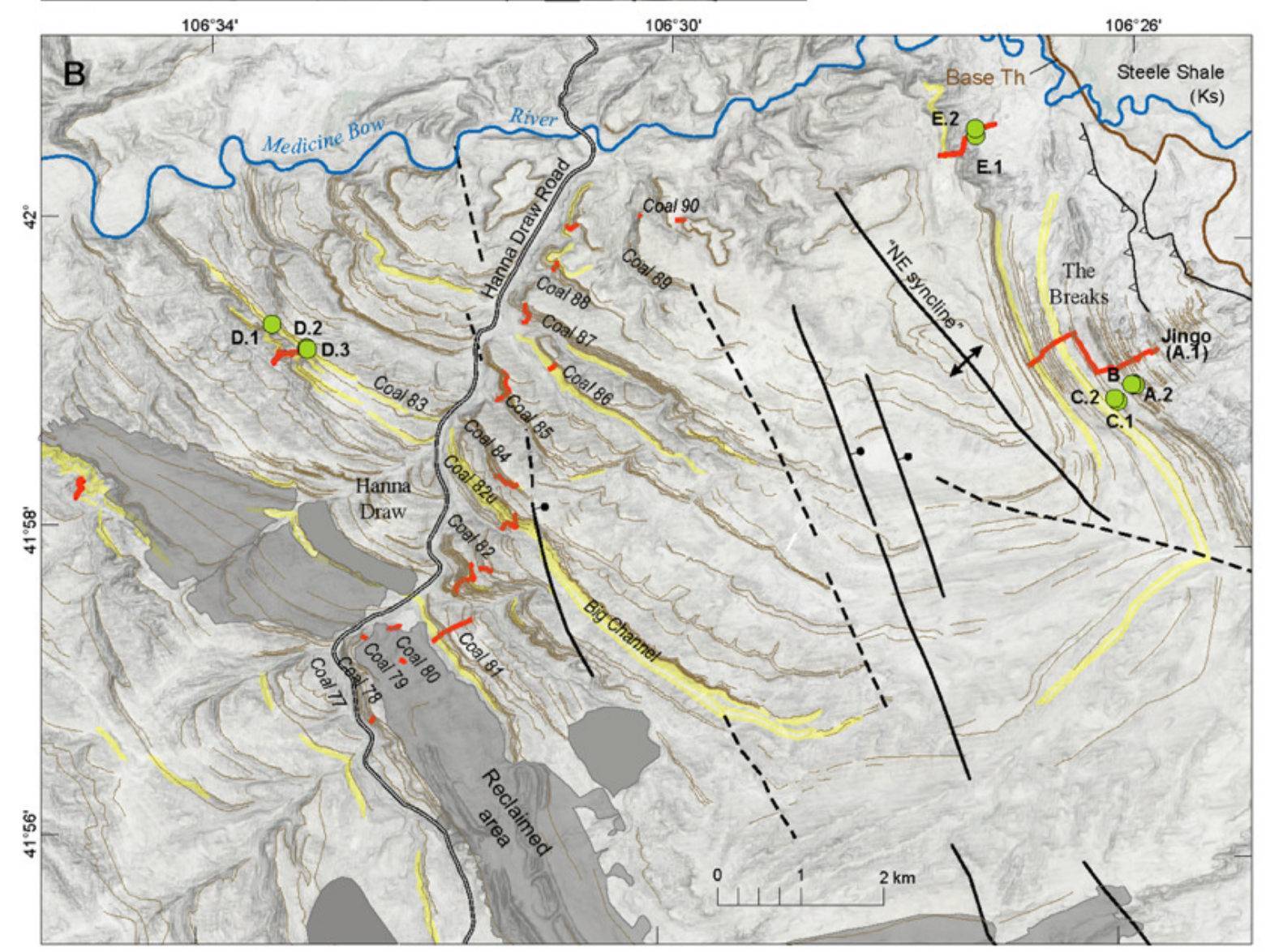


Figure 2

Stratigraphic column of Hanna basin, late Paleocene-Early Eocene

Stratigraphic placement for localities described in this paper within the Hanna Formation, along with correlations within the Hanna Basin. C numbers indicate coalbeds labeled after Dobbin et al. (1929), star indicates zircon date, a U/Pb concordia age of $54.42 \pm 0.27 \mathrm{Ma}$ was reported by Dechesne, pers. comm. (2019) but this date is likely a maximum estimate because the majority of zircons measured were detrital and the youngest dates were obtained from euhedral crystals.

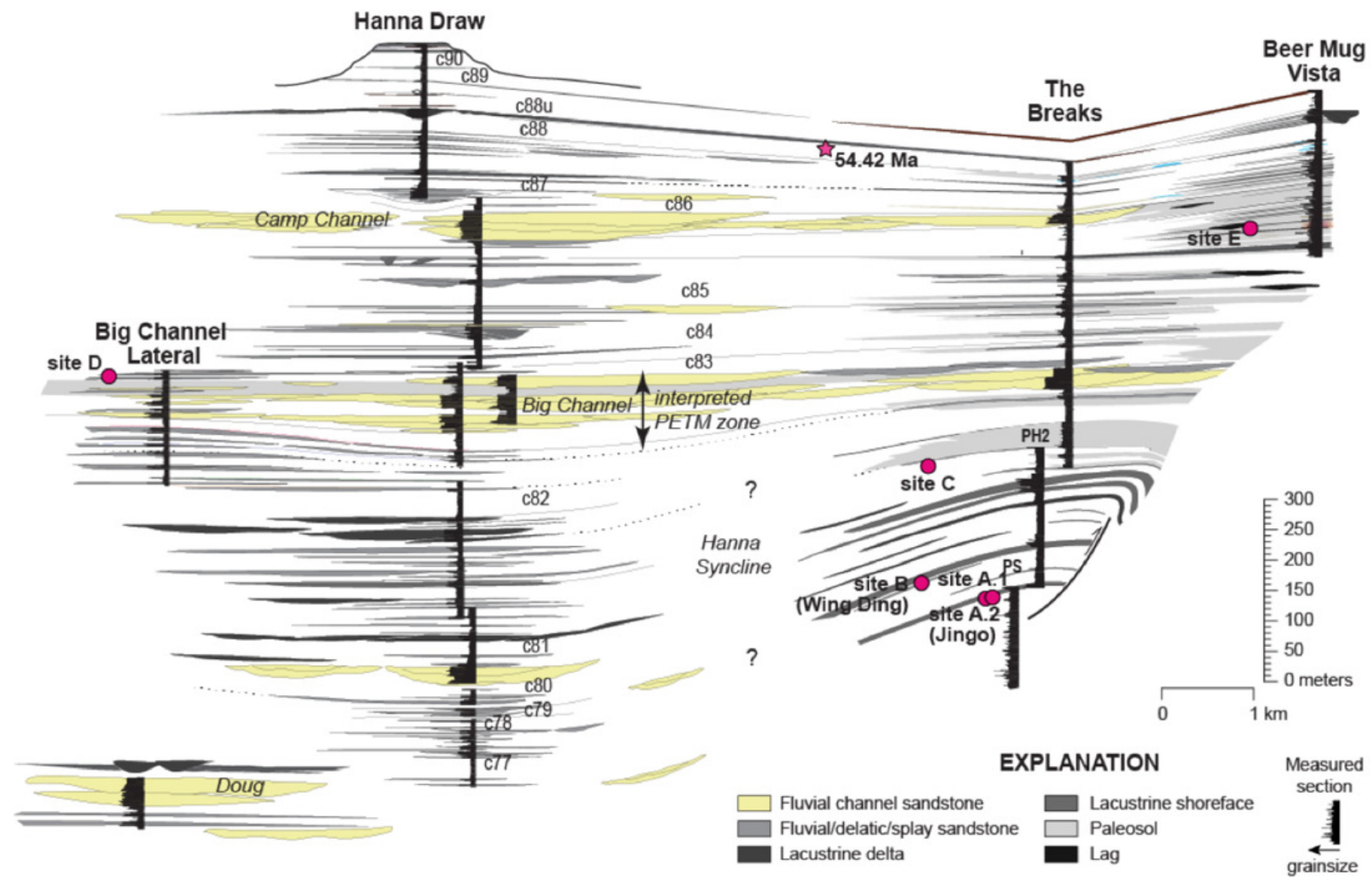




\section{Figure 3}

Common dicot leaf types from the late Paleocene and early Eocene in the Hanna Basin.

(A) unnamed dicot morphospecies HB174 (locality D, specimen \#PB928), (B)

Trochodendroides genetrix (locality A, specimen \#PB956), (C) unnamed dicot morphospecies HB176 (locality E, specimen \#PB978), (D) Palmate leaflet of Platanites raynoldsii(locality A, specimen \#PB968), (E) unnamed dicot morphospecies HB173 (locality D, specimen PB966), (F) Averrhoites affinis (locality C, specimen \#PB913), (G) unnamed dicot morphospecies HB180 (locality A, specimen PB1063). Scale bars are $1 \mathrm{~cm}$. 


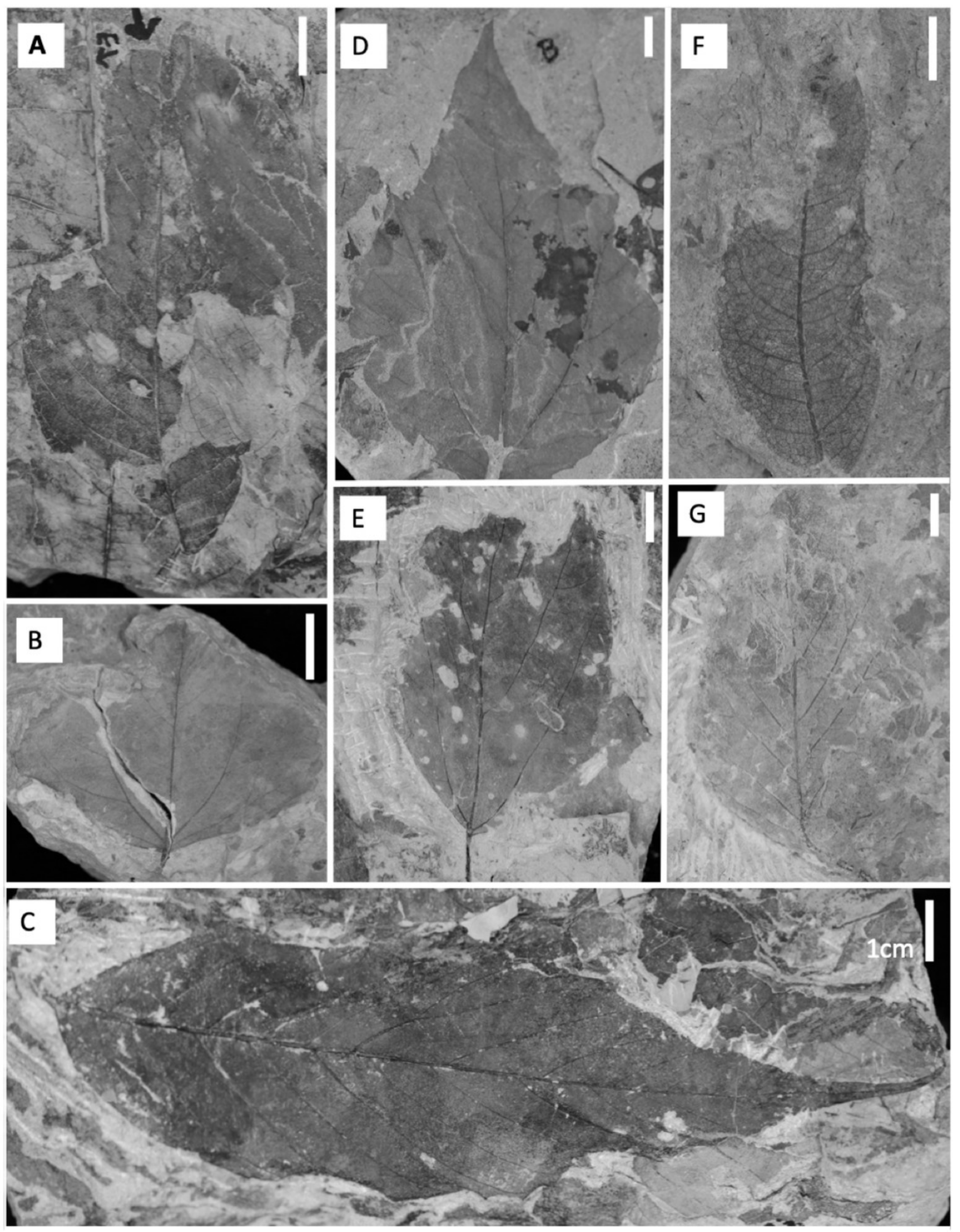


Figure 4

Rank abundance curve for all stratigraphic levels

Rank abundance curves for plant species at each stratigraphic level. Morphospecies with at least 45 specimens are labeled.

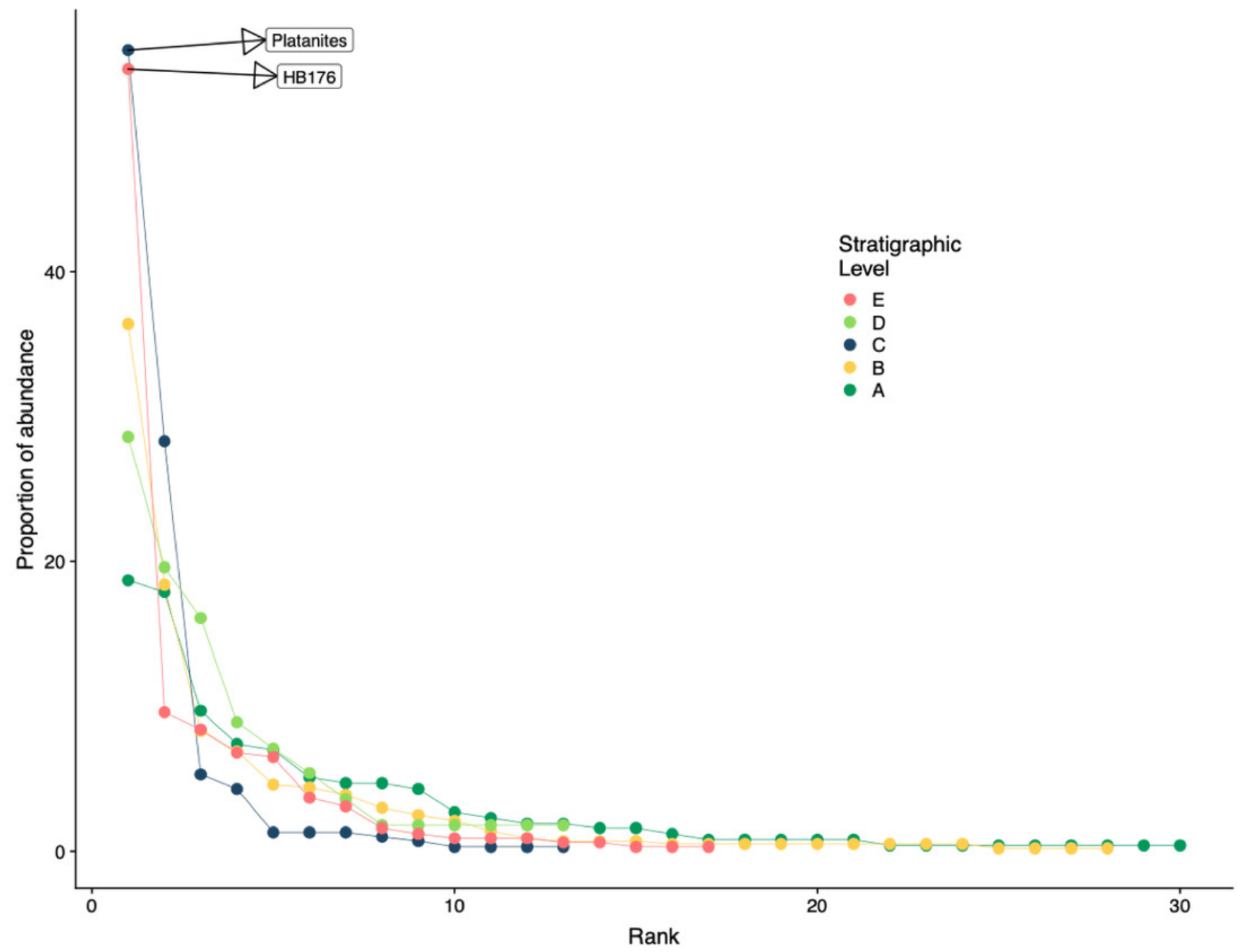


Figure 5

Plant and insect herbivore rarefaction curves

(A) Resampling curves of floral diversity, (B) total damage diversity on the bulk flora, and (C) specialized damage diversity on the bulk flora at each stratigraphic level. Gray ovals represent upper and lower confidence intervals (95\%) for each stratigraphic level. DT= damage morphotype.
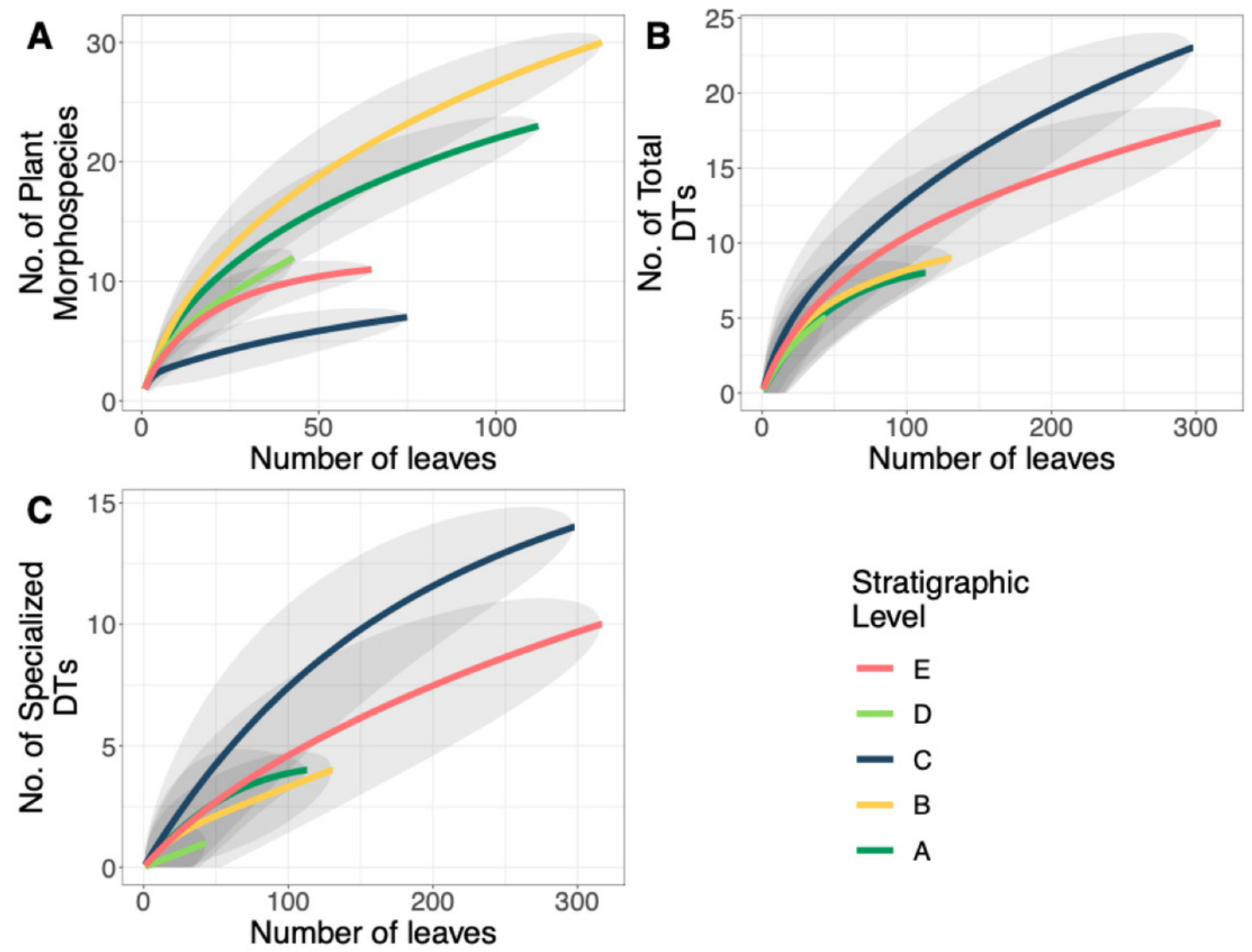

Stratigraphic

Level

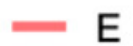

- D

- C

- B

- A 
Figure 6

Resampling curves of damage type (DT) richness on individual plant hosts that have 20 or more leaves at a single stratigraphic level.

Panel (B) is an enlargement of the lower left corner of panel (A). Platanites raynoldsii is the only species that occurred in high enough abundance at two stratigraphic levels (Levels C and E) to be able to compare damage diversity on a host plant. Gray ovals represent upper and lower confidence intervals (95\%) for each stratigraphic level.
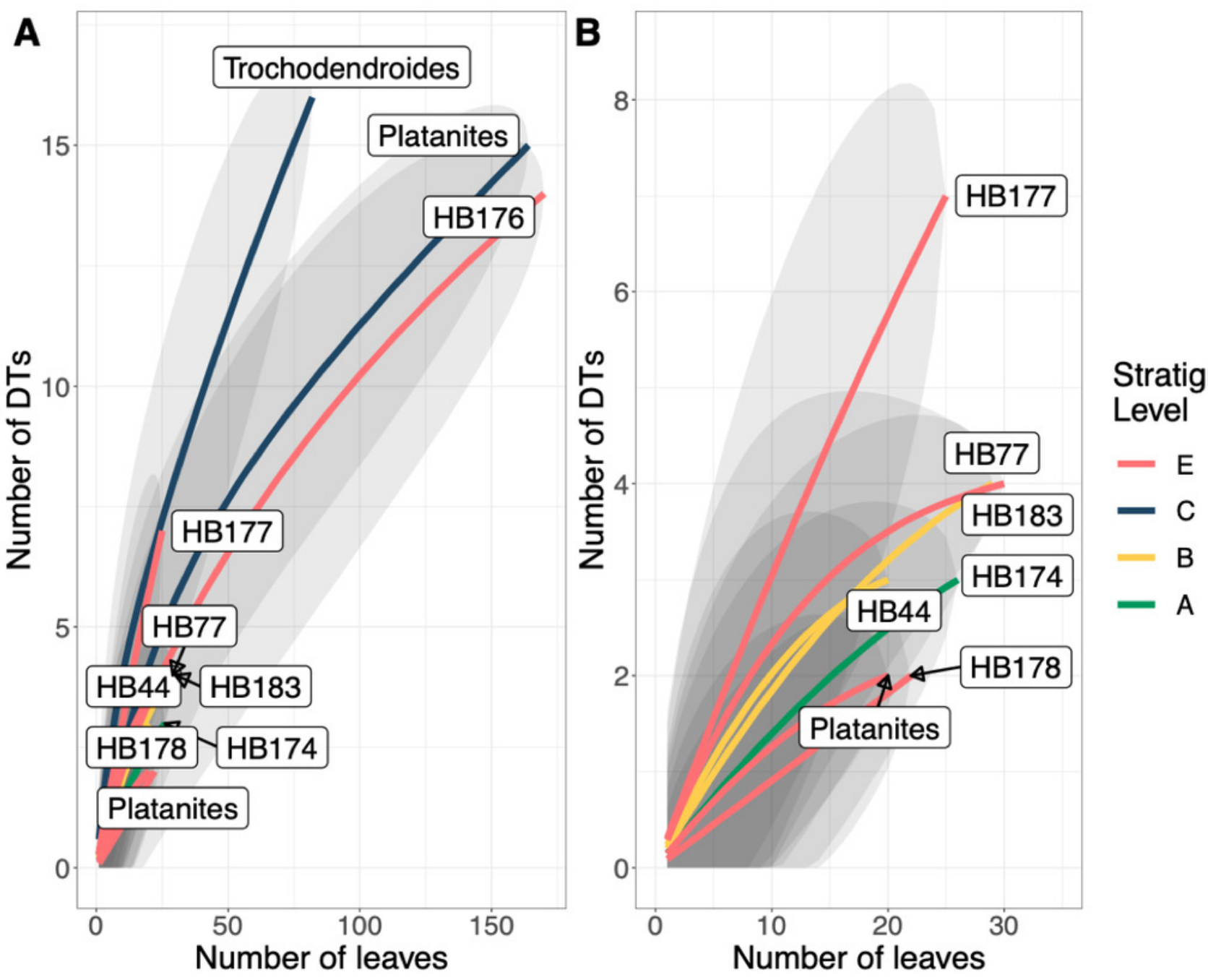


\section{Figure 7}

Insect damage frequency and ratio of specialized to general damage.

(A) Percent of leaves at each stratigraphic level with generalized, specialized and total insect herbivore damage. (B) The ratio of specialized feeding to generalized feeding at each stratigraphic level

A

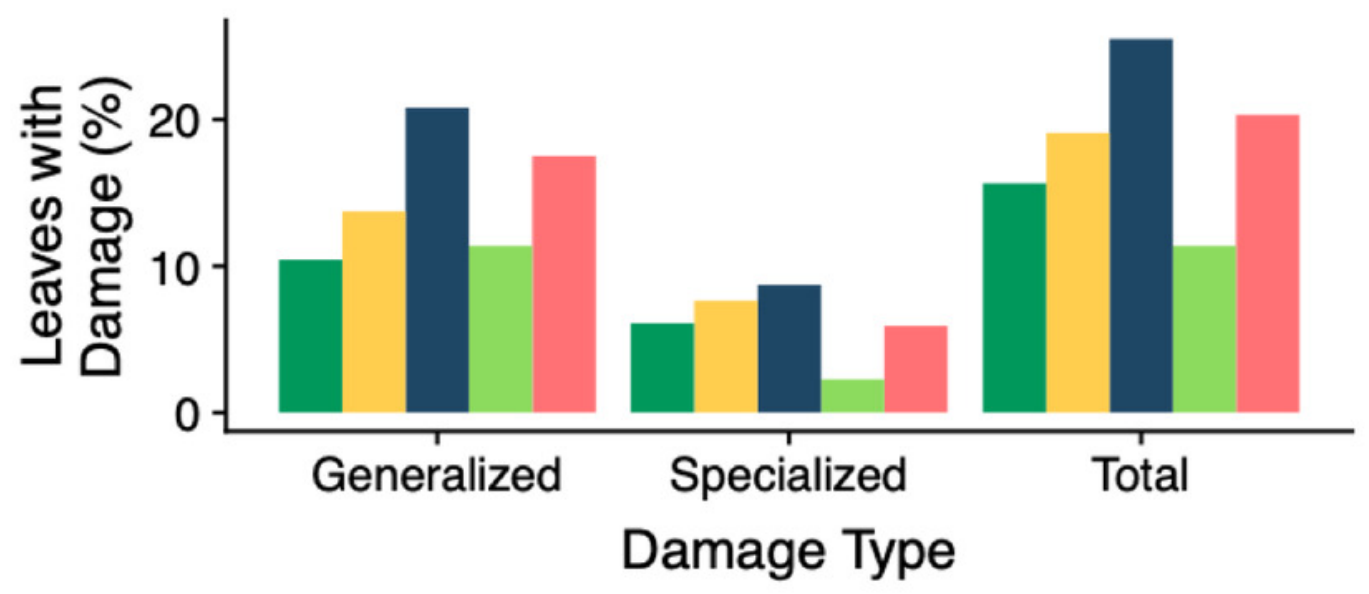

Stratigraphic Level

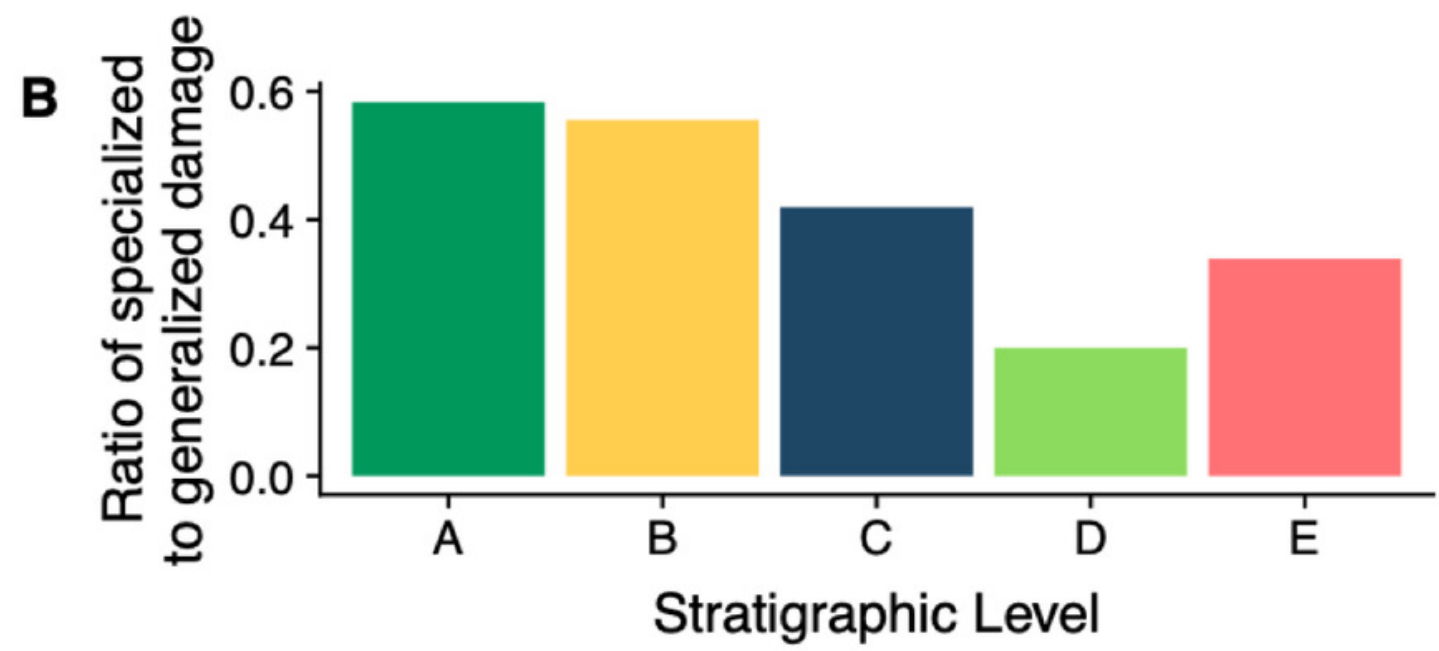




\section{Figure 8}

Damage type photos.

(A) HB177 (entire leaf) with damage (locality E, specimen \#PB976) (B) Close up image of A with damage believed to be caused by extant beetle family, Chrysomelid. (C) Damage on Platanites raynoldsiiwith DT38 (locality C, specimen \#PB922) (D) showing the close up of DT38.
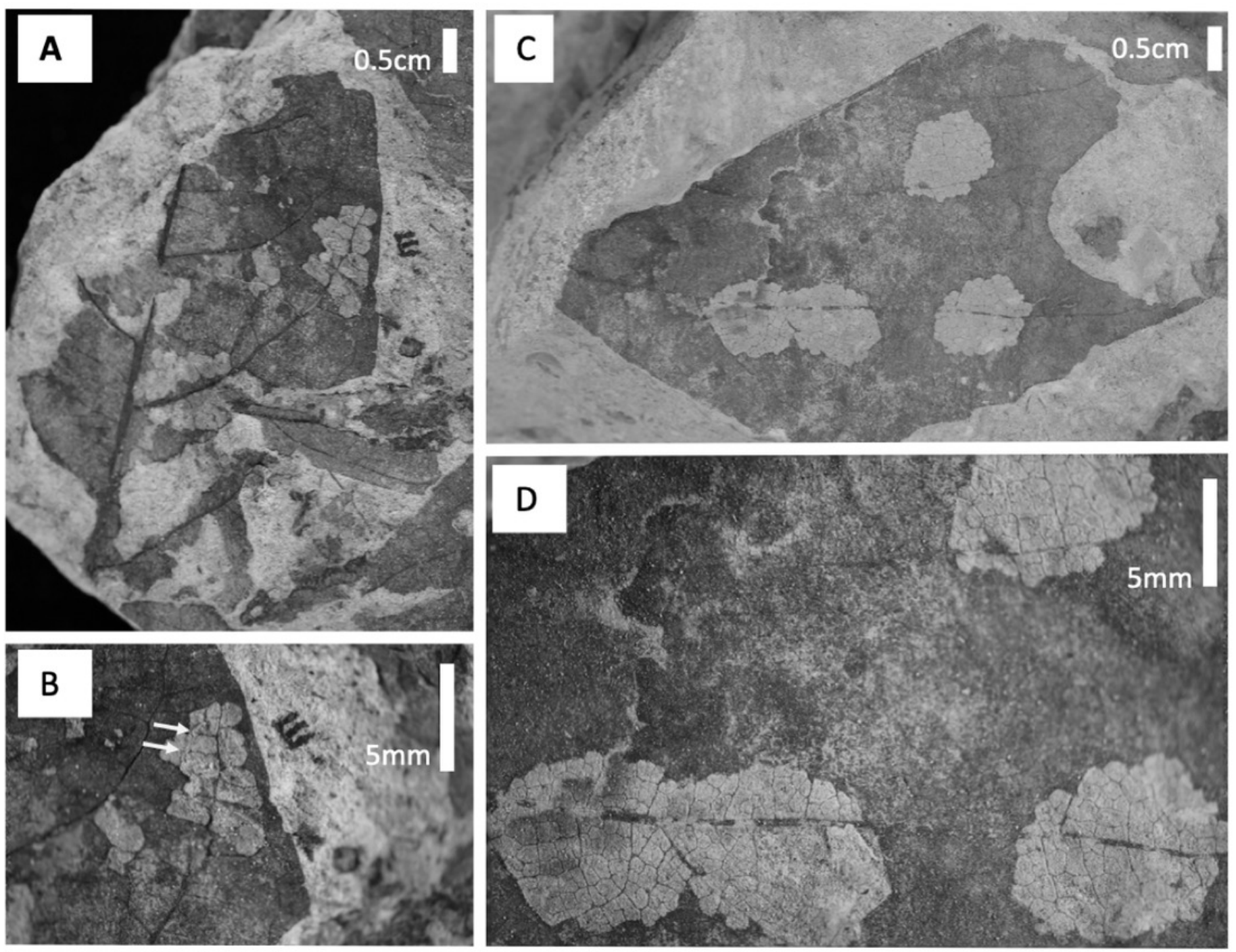


\section{Figure 9}

Nonmetric multidimensional scaling ordination

Nonmetric multidimensional scaling ordination of floral composition (A) and insect herbivory on the bulk floras (B) across all stratigraphic levels. The " $\mathrm{x}$ " symbols in figure A represent plant morphospecies and in Figure B represent insect herbivore damage types (DTs), labeled using the numbers of Labandeira et al. (2007). These are plotted to show their impact on the placement of each stratigraphic level. The unlabeled " $x$ " symbols affect the placement of the samples in the ordination, but for simplicity, only morphospecies or DTs that are abundant and explain separation of samples were labeled. Stress $<0.01$ for both plots.

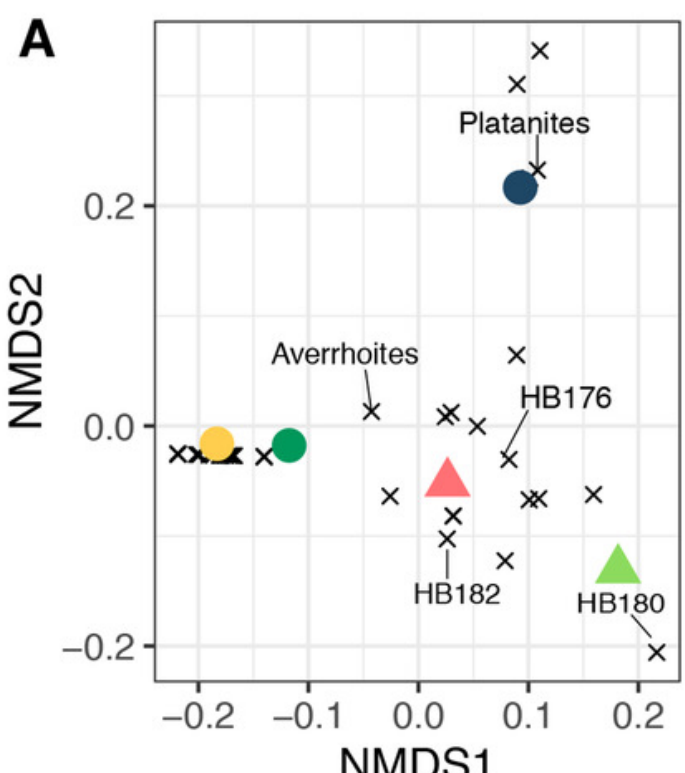

NMDS1

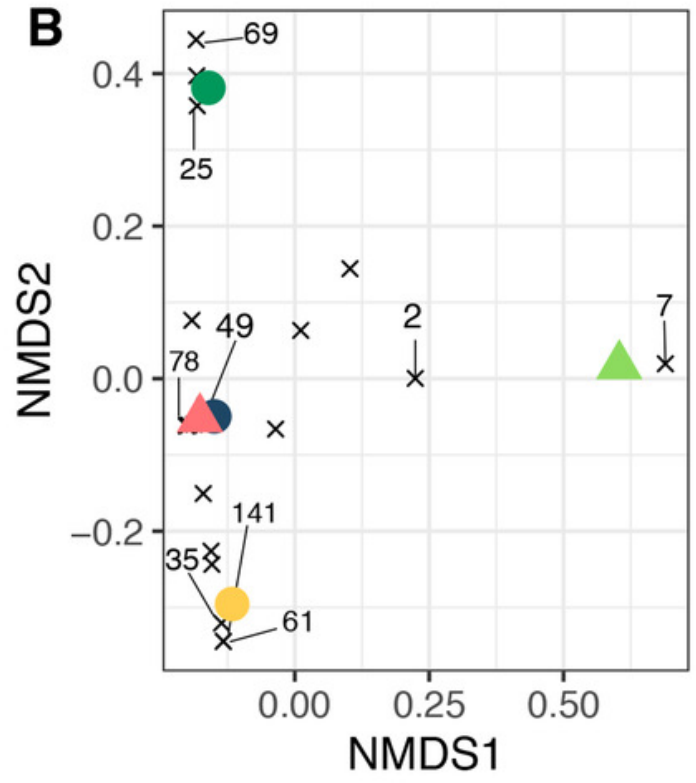

Stratigraphic Level

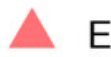

E

D

$B$

$A$ 